Review

\title{
Occupational Exposure to Mineral Dust in Mining and Earthmoving Works: A Scoping Review
}

\author{
Joana Duarte $^{1, * \mathbb{D}}$, Jacqueline Castelo Branco ${ }^{1}\left(\mathbb{D}\right.$, Fernanda Rodrigues ${ }^{2} \mathbb{D}$, Mário Vaz $^{1}(\mathbb{D})$ \\ and João Santos Baptista ${ }^{1} \mathbb{D}$
}

1 Associated Laboratory for Energy, Transports and Aeronautics (PROA/LAETA), Faculty of Engineering, University of Porto, 4200-465 Porto, Portugal; jcb@fe.up.pt (J.C.B.); gmavaz@fe.up.pt (M.V.); jsbap@fe.up.pt (J.S.B.)

2 Research Center for Risks and Sustainability in Construction (RISCO), University of Aveiro, 3810-193 Aveiro, Portugal; mfrodrigues@ua.pt

* Correspondence: jasduarte@fe.up.pt

check for updates

Citation: Duarte, J.; Castelo Branco, J.; Rodrigues, F.; Vaz, M.; Santos Baptista, J. Occupational Exposure to Mineral Dust in Mining and Earthmoving Works: A Scoping Review. Safety 2022, 8, 9. https:// doi.org/10.3390/safety8010009

Academic Editor: Tom Brijs

Received: 10 November 2021

Accepted: 26 January 2022

Published: 30 January 2022

Publisher's Note: MDPI stays neutral with regard to jurisdictional claims in published maps and institutional affiliations.

Copyright: () 2022 by the authors. Licensee MDPI, Basel, Switzerland. This article is an open access article distributed under the terms and conditions of the Creative Commons Attribution (CC BY) license (https:// creativecommons.org/licenses/by/ $4.0 /)$.

\begin{abstract}
Anthropogenic activity is related to several environmental imbalances, including dust. Particulate matter can also hinder humans with numerous health consequences, such as asthma, cancer, and pneumoconiosis. With a particular focus on mineral dust, this review is intended to determine in which circumstances occupational exposure occurs in the mining and earthmoving industries. Research followed the guidelines provided by the preferred reporting items for systematic review and meta-analysis protocols and its extension for scoping reviews. Of the 8993 records identified, only 24 passed both exclusion and inclusion criteria. Within the pool of results, it was possible to identify the following variables related to dust exposure: job-related (activity, job category, and site), engineering (equipment, transport system), technical (distance), and physical (season and weather) variables. Due to the significant variance in protocol settings, it was challenging to perform a general analysis, resulting in a study-by-study approach. The most significant conclusion of this study is not related to the setting of occupational exposure, although it derives from it. The necessity of adopting standard procedures for data collection, independent of research objective, was demonstrated within the context of occupational exposure to mineral dust.
\end{abstract}

Keywords: respirable dust; pollution; disease; equipment; task; extractive industry; quarrying; construction

\section{Introduction}

Air pollution related to particulate matter is a growing concern worldwide. The combination of airborne particulate matter and gaseous pollutants has the power to change the climate both locally and globally and is responsible for ozone depletion and acid rain [1]. However, this issue is not limited to the environment. It directly impacts human beings, both in relation to living conditions and health [2]. According to the World Health Organisation (https: / / www.who.int/news/item/02-05-2018-9-out-of-10-people-worldwidebreathe-polluted-air-but-more-countries-are-taking-action (accessed on 19 July 2021)) air pollution is a significant problem, as 9 out of 10 people breathe air containing high levels of pollutants, and around seven million people die every year from exposure to fine particles in polluted air.

The sources of air pollutants fall in one of two groups: point sources, which are easily identifiable and stationary; and fugitive sources, which are spatially distributed and cannot be linked to a specific point [3]. Specifically related to mineral dust, the Environmental Protection Agency (in the United States) categorises emissions into process dust and fugitive dust. Process dust can be captured (and mitigated). In contrast, fugitive dust is settled material transported by a the movement of machines or the wind [4]. It is known that dust emissions significantly impact air pollution and, consequently, human health [5]. Anthropogenic activities such as mining (and quarrying) and other earthworks involving 
off-road vehicles cause health-and-safety-related issues for the involved personnel, as well as environmental problems that can affect local communities [4,6]. Almost every activity in mining exploitation (drilling, blasting, crushing, conveying, transporting, etc.) contributes directly or indirectly to air pollution, particularly mineral dust emission [7].

The mineralogical and chemical composition, as well as mass and surface area of dust particles have direct impacts on health, with outcomes including lung cancer [8,9], bronchial asthma, chronic bronchitis [10,11], pneumoconiosis [12,13], pulmonary tuberculosis, occupational asthma [14], chronic obstructive pulmonary disease [9,10], dust-related fibrosis [15], cardiovascular disease, cerebrovascular disease [16], and gastric cancer [17]. A positive association reported between inhalable silica (from mining activities) and increased mortality in an exposure-response relationship, reflecting that this issue is a public health concern [7]. Recently, it was reported that in the U.K., 12,000 lung disease deaths per year are linked to past exposures at work. Moreover, between 2009 and 2019, the number of cases of occupational asthma reported by chest physicians progressively increased, which shows that this problem is far from being solved (https: //www.hse.gov.uk/statistics/causdis/respiratory-diseases.pdf (accessed on 19 July 2021)). Nonetheless, short-term exposure to respirable dust can also cause harm, especially in the upper respiratory tract, with symptoms such as coughing, difficulty breathing, and irritation of airways [18]. With a particular focus on the mining industry, besides duration of exposure, coexisting illnesses, and other risk factors, such as smoking [15], the severity and prevalence of the abovementioned occupational diseases are also related to the characteristics of the ore being exploited [14], as well as the geological characteristics of the mine [15]. Coal mining is still, among all mining, leading the increase in new cases of lung disease, particularly among young miners [15]. In fact, a positive correlation between coal mining and lung cancer has been observed [19].

Moreover, the size of pollutant particles is related to their ability to penetrate the respiratory system $[1,20]$. The inhalation of dust particles poses a significant issue because they cannot be exhaled or even cleared from the respiratory tract. They can remain within the breathing system for a long time [21]. By definition, dust comprises "solid particles of aerodynamic diameter less than $75 \mu \mathrm{m}$ " [13], consisting of different materials, such as minerals, as well as metallic and organic particles [21]. Depending on particle size, dust can be classified as suspended particles (in a range between 0.1 and $30 \mu \mathrm{m}$ diameter), inhalable dust $\left(\mathrm{PM}_{10}\right)$, respirable dust $\left(\mathrm{PM}_{4}\right)$, and particulate matter $\left(\mathrm{PM}_{2.5}\right)$ [3]. Still, another classification can also be found in literature: inhalable particles (size range from 10 to $20 \mu \mathrm{m}$ ), thoracic particles (size range between 4 and $10 \mu \mathrm{m}$ ), and alveolic particles (size range below $4 \mu \mathrm{m}$ ) [22]. Some studies suggest that $\mathrm{PM}_{2.5}$ can be more hazardous to human health than $\mathrm{PM}_{10}$ [1], leading to an increased variety of chronic diseases [23].

Due to the nature of mining and quarrying activities, every source has the potential to emit particulate matter [20]. Between 2000 and 2015, the Industrial Minerals Association (IMA-Europe) launched a dust monitoring program (DMP), collecting over 28,000 personal measurements of respirable dust and quartz in 23 European countries, leading to the creation of a database. This study used a standardised protocol regarding sampling methods, strategy, and even quality control of the retrieved data. For this reason, the data are comparable. However, the actual settings of such exposure were not determined. It is very demanding to proceed to dust measurements within actual operating conditions due to several factors, namely: study setup and measuring points [24]; weather conditions, such as wind speed, wind direction, presence of rain, and temperature [25]; and mining method [26].

Even though it is not possible to control production of pollutants, it should be manageable [26]. The most common dust-control strategy is to spray water over the target area [27]. Literature also suggests spraying liquid calcium chloride [22], synthetic-polymer-based products [5], or foam [27] as an alternative to water. Other processes include paving gravel roads, planting grasses, and setting a wall near the extraction area [28]. Adopting wet working methods or isolating dust sources (practically impossible in most cases) are also 
pointed to as possible control strategies [29] Other technologies are also suggested in this vein, such as cutting tools with reduced dust-generation mechanisms, such as ultrasonic dust-suppression systems [30]. Timely inspection and equipment maintenance can also serve as preventive measures [29]. A simple traffic-control process is thought to decrease the dust if trucks enter the loading area at least 20 to $30 \mathrm{~s}$ apart [31]. Despite their practicality, these examples only mitigate the problem rather than solving it. In this sense, the main objective of this scoping review was to determine in which circumstances dust exposure occurs. By collecting data to answer the previous point, it may be possible to design tasks (and the exploitations themselves) in order to diminish this problem. This analysis is intended to guide the (re)formulation of strategies to improve occupational health and environmental settings [32].

\section{Methodology}

The study methodology was based on the protocol for scoping review [33] using the preferred reporting items for systematic review and meta-analysis protocols (PRISMA-P) [34] and the extension for scoping reviews [35].

The first step of the research was to identify the main databases/journals to search for information. In that sense, according to the availability of such databases and journals, the ones related to the engineering field or multidisciplinary sciences were selected: Web of Knowledge (Current Contents and Web of Science), Scopus, SAGE journals, Academic Search Ultimate, American Chemical Society, Directory of Open Access Journals (DOAJ), Elsevier (Science Direct), Emerald, INSPEC, IEEE Xplore, Taylor and Francis, and PubMed. Despite the focus of this scoping review on the extractive industry rather than the construction industry, in the latter, dust emission also constitutes one of the most common risks. Reported activities such as soil loading and transporting, excavation, and other road construction tasks [36] have common ground with the primary research objective of this scoping review. Therefore, this field was also considered in a first approach. The selected keywords to conduct the research were: "dust", "dusting", "particulate", "powder", and "crystalline silica", combined sequentially with "road construction", "earthworks", "open pit", "open cast", "quarry", "mining industry", and "extractive industry", resulting in 35 different combinations. Whenever possible, the keywords were searched in "Title+Abstract+Keywords"; other possibilities included: topic, title, or even abstract. Then, a set of exclusion criteria was applied to filter the best information in the first stage of research: (1) year: only papers published between 2015 and 2020 were considered; (2) type of document: research articles (articles, articles in press); (3) type of source: peer-reviewed journals; (4) language: English. In the second stage of research, all types of literature published prior to 2015 were considered, as proposed by the snowballing technique [37]. The eligibility criteria were applied on a study level. The authors were mainly interested in real operating conditions (field data) related to dust exposure/measurements in three different settings: road construction, earthworks, and open-pit mining. This research and the first screening phase were conducted by one researcher and confirmed by the second researcher. All of the extracted data were analysed by three independent researchers and confirmed by a fourth.

The primary information from each study was extracted [33]: author (and year of publication), study objective, activity, exploited material (whenever applicable), analysed substance, period (of the experiment), ethical committee, informed consent, population, sample, age, sex, control group, (used) standards, duration of the occupational exposure, source of exposure, methodology, measuring equipment, equipment calibration, sampling time, questionnaire, validation, reported symptoms, results, and limitations. However, due to the variability of information, it was impossible to cross examine the collected data. The reported measurements were classified according to the available data (study variables and experimental protocols) and gathered in form sheets. Analysis of the information was carried out at the study level. 
The PRISMA guidelines include a section related to risk of bias [34]. Bias can refer to any error introduced in research that may result in misleading results. The risk of bias within studies was assessed with one of three possible classifications [38]: "high risk": the parameter has a significant effect on the results; "low risk": the parameter does not have a significant impact on the results; "unclear risk": it is not possible to characterise the effect of the parameter on the obtained results. The analysed parameters were included in tableform in two categories: methodology and other. Methodology included task definition, equipment type and standard application, measurement precision, sampling time, sample representativeness, and equipment calibration; in the other category included reporting quality and reference quality.

The first research step was carried out between July and October 2020 and updated in October 2021.

\section{Results}

From the 8993 records found in the identification phase of the PRISMA methodology [39], 4923 were excluded after applying the first exclusion criterion (article published before 2015), 896 were removed due to document type (only research articles were considered), 26 were excluded due to source type (only peer-reviewed journal articles were considered), 161 were removed due to language (only papers written in English were included), and 2776 were excluded for being off-topic (in light of the objectives proposed by this scoping review). Additionally, 160 duplicated records were removed. A total of 51 studies were assessed for eligibility, excluding 35 records that did not provide rationale nor measurements of dust levels in any of the considered settings. From the same analysis, six additional records were identified as new sources of information. During the research update in October 2021, two more papers were added to the study. A total of 24 papers were included in this study. The summary can be found in Figure 1.

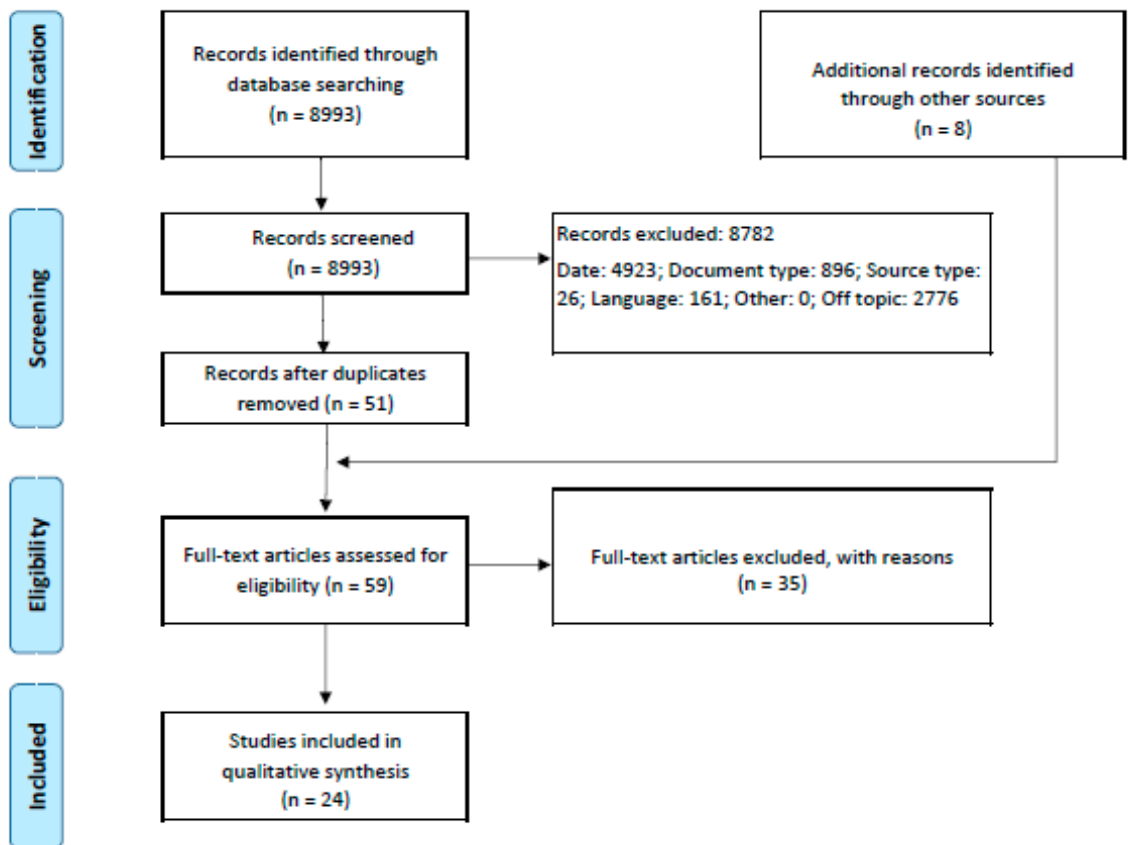

Figure 1. Summary of the research, adapted from Moher et al. [39].

Using VOSviewer [40], it was possible to identify five clusters for the most used terms in the set of included papers and the relations between them (Figure 2). Cluster 1: assessment, particulate, $\mathrm{PM}_{10}$, range, workplace; cluster 2: concentration, distance, drilling, quarry, source; cluster 3: dust, exposure, haul truck, respirable dust, worker; cluster 4: depth, pit, time; and cluster 5: dust concentration, sample. 


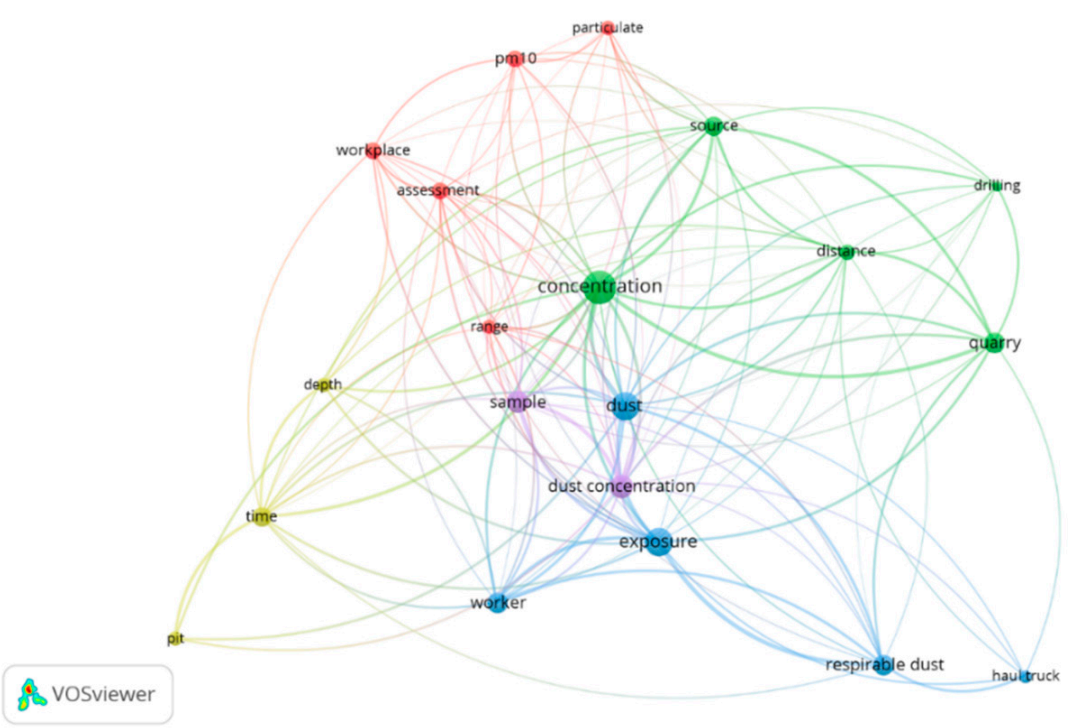

Figure 2. Keywords relations between studies.

As previously, articles were classified according to their research variables, where there was significant heterogeneity, as well methodologies used for data collection. Additionally, country of origin, dust-exposure-limit value (sought for in international norms whenever (frequently) it was not provided on the paper), activity, location type, and exploited material were also considered. It is important to not that, concerning "dust exposure limit", the difference in results is due to classification. For instance, the value provided for Finland is related to occupational exposure to respirable silica dust, whereas for Taiwan, it is related to total suspended particles for a daily standard. This information is summarised in Table 1.

Of the analysed studies, only one [43] was conducted in a construction-site environment; all other studies concerned mines or quarry sites. The exploited materials were, from the most commonly to least commonly exploited: coal $[6,22,30-32,41,44,52,56]$, iron [25,42], limestone [28,53], aggregates [24,51], taconite [47], granite [46], sandstone [55], copper [45], gold [48], platinum [54], and manganese [25].

Regarding "studied variables", most were inferred from the experimental protocol of each article's methodology, as each study's outcome was not solidly related to the variable itself. Therefore, each study was classified into one (or more) of the following categories:

- Job-related variables: activity, job category, site;

- Engineering variables: equipment, transport system;

- Technical variables: distance;

- Physical variables: season, weather.

Tables with the extracted data from each of the studies can be found in the Appendix A, divided into three parts: (1) paper-related data, general information, and people-related data (Table A1); (2) occupational exposure (Table A2); and (3) prevalence and main findings (Table A3).

Despite the experimental protocol of each paper, only 15 out of the 24 papers referred to dust-particle size $[6,22,24,25,28,31,43-45,48,49,51,52,55,56]$. The remaining papers did not specify this parameter, despite mentioning "respirable dust" [41,47,53], "respirable and inhalable" [42,54], or just "dust" [32,50]. From the analysed data, two studies discussed quartz analysis in addition to dust [30,46], and two other referred specifically to silica [41,47]. Further information, such as the source of exposure and sampling methodology, including equipment, calibration, sampling time (duration) and sampling frequency is also described. The source of exposure differed according to each study's particular objective: specific equipment, (e.g., crusher) [46]; activity (transport, drilling, crushing), dust measurements from defined locations; or personal exposure to dust $[30,47,50,53,54]$. Of the studies analysing personal exposure, only one reported the demographic data of workers [54]. 
Table 1. Study analysis regarding dust-exposure limit, activity and location, exploited material, and variables.

\begin{tabular}{|c|c|c|c|c|c|c|c|}
\hline Author (year) & Country & Dust Limit & Source & Activity & $\begin{array}{l}\text { Location } \\
\text { Type }\end{array}$ & $\begin{array}{l}\text { Exploited } \\
\text { Material }\end{array}$ & Studied Variables \\
\hline Chang (2004) [28] & Taiwan & $0.25 \mathrm{mg} \cdot \mathrm{m}^{-3}$ & Referred in article & Mining & Quarry & Limestone & $\begin{array}{l}\text { Distance, season, } \\
\text { transport system, } \\
\text { weather }\end{array}$ \\
\hline Reed \& Organiscak (2005) [31] & USA & $2 \mathrm{mg} \cdot \mathrm{m}^{-3}$ & Sought for & Mining & Quarry, mine & Stone, coal & Not mentioned \\
\hline Onder \& Yigit (2009) [41] & Turkey & $5 \mathrm{mg} \cdot \mathrm{m}^{-3}$ & Referred in article & Mining & Mine & Coal & Activity, site \\
\hline Gholami et al. (2012) [42] & Iran & $4 \mathrm{mg} \cdot \mathrm{m}^{-3}$ & Sought for & Mining & Mine & Iron & Site \\
\hline Faber et al. (2015) [43] & Germany & $3 \mathrm{mg} \cdot \mathrm{m}^{-3}$ & Sought for & $\begin{array}{c}\text { Earthworks, } \\
\text { road construction }\end{array}$ & Construction site & Not applicable & Activity, equipment \\
\hline Sastry et al. (2015) [44] & India & $3 \mathrm{mg} \cdot \mathrm{m}^{-3}$ & Sought for & Mining & Mine & Coal & Distance, weather \\
\hline Gautam et al. (2016) [45] & India & $3 \mathrm{mg} \cdot \mathrm{m}^{-3}$ & Sought for & Mining & Mine (3) & Copper & Activity, site \\
\hline Amran et al. (2017) [46] & Malaysia & $3 \mathrm{mg} \cdot \mathrm{m}^{-3}$ & Referred in article & Mining & Quarry (9) & Granite & Activity, equipment \\
\hline Hwang et al. (2017) [47] & USA & $2 \mathrm{mg} \cdot \mathrm{m}^{-3}$ & Sought for & Mining & Mine (6) & Taconite & Job category \\
\hline Pandey et al. (2017) [30] & India & $3 \mathrm{mg} \cdot \mathrm{m}^{-3}$ & Referred in article & Mining & Mine (7) & Coal & Job category \\
\hline Rabeiy et al. (2018) [48] & Egypt & $3 \mathrm{mg} \cdot \mathrm{m}^{-3}$ & Referred in article & Mining & Mine & Gold & Site \\
\hline Rusibamayila et al. (2018) [50] & Tanzania & $5 \mathrm{mg} \cdot \mathrm{m}^{-3}$ & Referred in article & Mining & Mine & Gold & Activity, job category \\
\hline Sahu et al. (2018) [22] & India & $3 \mathrm{mg} \cdot \mathrm{m}^{-3}$ & Sought for & Mining & Mine (2) & Coal & Weather \\
\hline Sairanen \& Selonen (2018) [51] & Finland & $0.1 \mathrm{mg} \cdot \mathrm{m}^{-3}$ & Sought for & Mining & Quarry (2) & Aggregates & Not mentioned \\
\hline Tripathy \& Dash (2018) [6] & India & $3 \mathrm{mg} \cdot \mathrm{m}^{-3}$ & Referred in article & Mining & Mine & Coal & Activity, season, site \\
\hline Wanjun \& Qingxiang (2018) [52] & China & $4 \mathrm{mg} \cdot \mathrm{m}^{-3}$ & Not applicable & Mining & Mine & Coal & Activity \\
\hline Chaulya et al. (2019) [25] & India & $3 \mathrm{mg} \cdot \mathrm{m}^{-3}$ & Sought for & Mining & Mine & Iron, manganese & Activity \\
\hline Mankar et al. (2019) [53] & India & $3 \mathrm{mg} \cdot \mathrm{m}^{-3}$ & Referred in article & Mining & Mine & Limestone & Activity \\
\hline Sairanen \& Rinne (2019) [24] & Finland & $0.1 \mathrm{mg} \cdot \mathrm{m}^{-3}$ & Sought for & Mining & Quarry (6) & Aggregates & Not mentioned \\
\hline Tong et al. (2019) [32] & China & $4 \mathrm{mg} \cdot \mathrm{m}^{-3}$ & Referred in article & Mining & Mine & Coal & Job category \\
\hline Sepadi et al. (2020) [54] & South Africa & $3 \mathrm{mg} \cdot \mathrm{m}^{-3}$ & Referred in article & Mining & Mine (2) & Platinum & Equipment, site \\
\hline Ambastha \& Haritash (2021) [55] & India & $3 \mathrm{mg} \cdot \mathrm{m}^{-3}$ & Referred in article & Mining & Quarry & Sandstone & Site \\
\hline Trechera et al. (2021) [56] & China & $4 \mathrm{mg} \cdot \mathrm{m}^{-3}$ & Sought for & Mining & Mine & Coal & Site \\
\hline
\end{tabular}


Regarding the data-collection process, 10 out of the 24 articles used or applied the experimental protocol through standards: American Society for Testing and Materials (ASTM) [31,56]; International Organisation for Standardisation, ISO-589 (1981), ISO-1171 (1976), and ISO-562 (1974) [56]; National Institute for Occupational Safety and Health, (NIOSH) 0600 [46,47], NIOSH 7500 [42,47], and NIOSH 7602 [54]; National Ambient Air Quality Standards, NAAQS 2009 [6], Directorate General of Mines Safety of India [30,53]; and the Chinese Ministry of Health [32]. Additionally, each study applied its own experimental protocol (time sampling, frequency, among other variables), making it almost impossible to compare the various studies.

\section{Discussion}

The analysis provided by VOSViewer [40] showed that the controlled terms related to the papers were grouped in five clusters that, with various links between them. All of the identified clusters were related to the research objective and selected terms, although some keywords reflected the articles' specific scope. Interestingly, two of the cluster concepts were "drilling" and "haul truck", specific situations within the research results.

However, contrary to initial expectations, it was impossible to find a common approach among the reviewed studies, considering the quality and evidence criteria placed in their selection. The difference between the variables and approaches used by the working groups made it impossible to achieve a coherent and integrative view of the research carried out in this area. However, a positive aspect is that it was possible to identify a set of relevant work that allowed for the identification of critical areas where it is essential to deepen the research in order to complement and confirm the obtained results.

Thus, our analysis will be carried out topic by topic, considering the collected data and their classification according to the variables presented in Table 1 . The discussion will be oriented towards analysis, considering: job-related variables, engineering variables, technical variables, and physical variables.

\subsection{Job-Related Variables}

\subsubsection{Activity}

Among all the eligible papers, nine collected dust samples concerning activities, which are described in Table $2[6,25,41,43,45,46,50,52,53]$.

Table 2. Activity per study.

\begin{tabular}{cc}
\hline Study & Activity \\
\hline$[41]$ & Overburden loading, coal loading, drilling \\
\hline$[43]$ & Earthworks \\
\hline$[45]$ & Mining \\
\hline$[46]$ & Crushing (primary, secondary, tertiary) \\
\hline$[50]$ & Haulage, loading materials, clearance and pushing materials, measuring \\
& the depth of holes \\
\hline$[6]$ & Vehicular movement, mining \\
\hline$[52]$ & Mining, transportation, dumping \\
\hline$[25]$ & Loading point, transport, vehicular movement, truck movement \\
\hline
\end{tabular}

In Table 3, results are presented with their respective units [41,50,52,53]. Activities such as drilling [41,53], blasting, loading, shovelling, and transportation [53] were stressed tasks leading to high dust concentrations. However, spraying with water, which is present, for instance, in some drilling systems, also did not prove to be significantly more effective when compared to other solutions [41]. 
Table 3. Dust concentration according to performed activity.

\begin{tabular}{|c|c|c|c|c|}
\hline Activity & $\begin{array}{l}8 \mathrm{~h} \text { conc. } \\
\left(\mathrm{mg} \cdot \mathrm{m}^{-3}\right)\end{array}$ & $\begin{array}{c}\text { Range } \\
\left(\mathrm{mg} \cdot \mathrm{m}^{-3}\right)\end{array}$ & $\begin{array}{c}\text { Range } \\
\left(\mu \mathrm{g} \cdot \mathrm{m}^{-3}\right)\end{array}$ & Study \\
\hline Overburden loading & - & $0.10-3.50$ & - & \multirow{3}{*}{ [41] } \\
\hline Coal loading & - & $0.25-2.10$ & - & \\
\hline Drilling & - & $0.48-7.29$ & - & \\
\hline Haulage & - & $0.09-0.27$ & - & \multirow{4}{*}[50]{} \\
\hline Loading materials & - & $0.10-0.33$ & - & \\
\hline Clearance and pushing materials & - & $0.10-0.32$ & - & \\
\hline Measuring the depth of holes & - & $0.21-0.61$ & - & \\
\hline Mining & - & - & $31.3-117.6$ & \multirow{3}{*}{ [52] } \\
\hline Transportation & - & - & $31.3-112.4$ & \\
\hline Dumping & - & - & $47.5-127.8$ & \\
\hline Transfer ore from belt conveyor 1 to belt conveyor 2 (PD1) & 0.43 & - & - & \multirow{24}{*}{ [53] } \\
\hline Transfer ore from belt conveyor 1 to pipe conveyor (PD2) & 1.04 & - & - & \\
\hline Shovel operation (PD3) & 0.37 & - & - & \\
\hline Dumper operation (PD4) & 0.43 & - & - & \\
\hline Shovel operation (PD5) & 0.39 & - & - & \\
\hline Drill helper (PD6) & 0.32 & - & - & \\
\hline Dumper operation transferring ore to crusher (PD7) & 0.40 & - & - & \\
\hline Dumper loading to crusher (AD1) & 0.54 & - & - & \\
\hline Crushing of limestone (AD2) & 0.25 & - & - & \\
\hline Transfer limestone from belt conveyor to pipe conveyor (AD3) & 0.27 & - & - & \\
\hline Dumper movement (AD4) & 0.25 & - & - & \\
\hline Dumper and other service vehicle movement (AD5) & 0.33 & - & - & \\
\hline Backhoe operator loading onto tipper (PD8) & 0.80 & - & - & \\
\hline Backhoe loading overburden onto tipper (PD9) & 1.04 & - & - & \\
\hline Tata Hitachi operation (PD10) & 0.85 & - & - & \\
\hline Dumper operation (PD11) & 0.66 & - & - & \\
\hline Dumper operation (PD12) & 0.62 & - & - & \\
\hline Drilling operation (PD13) & 1.23 & - & - & \\
\hline Movement of dumpers, tipper, and mine vehicles (AD6) & 1.14 & - & - & \\
\hline Drilling operation (AD7) & 1.52 & - & - & \\
\hline Shovel loading overburden onto tipper (AD8) & 1.42 & - & - & \\
\hline Dumper loading ore onto tipper (AD9) & 1.04 & - & - & \\
\hline Transfer ore from one conveyor to another (AD10) & 2.64 & - & - & \\
\hline Transfer ore from the belt conveyor to pipe conveyor (AD11) & 1.52 & - & - & \\
\hline
\end{tabular}

8 h conc.: 8-h concentration; PD: personal dust; AD: area dust;- - No available information.

Only one study reported dust-concentration measurements for an eight-hour period, therefore comparable with the standards [53], with every value below the permissible limit ( $3 \mathrm{mg} \cdot \mathrm{m}^{-3}$ in India, where it took place). However, the authors note that the experimental protocol was applied right after the rainy season, affecting the measurements. Nonetheless, the influence area of the transfer point between the crusher's discharge belt and another belt (AD10) presents $75 \%$ of the permissible limit.

Overall, rock cutting/crushing operations are generally a dry process and generate large amounts of respirable dust $[30,47]$. In crushing operations, tertiary crushing generates twice the amount of particles as secondary crushing [24]. Focusing mainly on respirable crystalline silica, it was possible to conclude that the combination of secondary and tertiary crushing plants leads to higher concentrations of this substance [46]. On the other hand, this dust concentration can be lower during milling, as this process is usually wet [47]. Comparing crushing and drilling, the former produces more coarse particles than the latter [8].

\subsubsection{Job Category}

The relationship between worker job and dust exposure was referred to in four studies $[30,32,47,50]$. 
In one of the studies, independent of the mining sector (mining, crushing, concentrating, pelletising, shop mobile, shop stationery, and office/control room), the maintenance technician was the worker associated with higher exposure to dust [47]. This conclusion was found across the analysed mines due to the similarity in mining and processing of taconite.

However, the general results show that workers performing activities directly related to dust generation, such as (manual) drill operators [32] and the quality controllers (of the holes, in blasting) [50], were the ones showing higher exposure to dust. On the contrary, the measures taken of truck operators, excavator operators, and dozer operators, besides not being statistically different, showed that working inside cabins with air-conditioning systems decreases exposure to dust [50]. Despite the fact that this relation was not directly assessed, one of the studies reported that workers engaged in crushing activities, loading crushed material and drilling, are more vulnerable to such exposure [55].

Other authors analysed jobs in different mining operations, organising the results according to increasing particle-size exposure. Machine-operator exposure occurs with particle sizes between 2 and $3 \mu \mathrm{m}$; drill operator, dozer operator, and shovel operator between, 4 and $5 \mu \mathrm{m}$; and cable man, between 7 and $8 \mu \mathrm{m}$. These professions report exposure to particles with an average size below $10 \mu \mathrm{m}$.

Processes involving cutting rock generate many fine particles, which usually leads to higher dust-exposure values. In this study, more than $50 \%$ of the total samples above the maximum exposure limit contained particles of less than $5 \mu \mathrm{m}$. This issue is of particular concern since it is evidenced in the literature that sizes of this order of magnitude are potentially the leading cause of numerous lung-related chronic diseases [47].

\subsubsection{Site}

Eight selected studies analysed specific-site (location) dust concentrations [6,41,42,45,48,54-56].

Drilling is one of the most hazardous activities when considering exposure to dust [41]. The face of operation was found to have measurements with higher particle concentrations. Additionally, coal-handling plants and stockyards were also referred to as critical locations. Regardless of particle type (measured respirable dust concentration or total dust concentration), extraction site and crusher section are two sites with higher dust levels in the long run. In contrast, in administration offices, the results show the most negligible dust content [42]. This is in line with the observations from other studies [48].

Particle travel time was evaluated in one of the reviewed field studies [45]. Its results showed that it takes nearly one hour for a particle to travel from a depth of $168 \mathrm{~m}$ to the pit surface and that this happens independent of particle size. However, when an open-pit mine is exploited at more shallow depths, the travelling time between benches (10 $\mathrm{m}$ apart) is only $7 \mathrm{~min}$. Analysis of different scenarios (in more than one mine) led the authors to conclude that mine geometry is essential when reflecting upon occupational exposure parameters. The same study also showed that the dust concentration was higher at the source of exposure and decreased in every direction.

Additionally, and with relation to particle size, the results point out that alveoli particle matter disperses more quickly than larger particles (thoracic and inhalable). Only 9 to $30 \%$ of alveolic particles settle within a (vertical) distance of between $18 \mathrm{~m}$ and $20 \mathrm{~m}$, compared to $19 \%$ to $37 \%$ of thoracic and $23 \%$ to $39 \%$ of inhalable particles. Another study concluded that smaller particles can travel great distances, even affecting the populations in the vicinity of mines [55].

\subsection{Engineering Variables}

\subsubsection{Equipment}

Only three studies referred to a link between dust concentration and equipment $[43,46,54]$.

Few pieces of equipment were mentioned in the studies, but some conclusions could be drawn from analysis of the available data. Trucks travelling along unpaved roads are 
related to high dust concentrations [43]. The same study remarked that rollers generate mostly coarse particles as a dust source.

The crusher is also one of the most frequently mentioned pieces of equipment when analysing dust concentrations, especially in plants that combined secondary and tertiary crushing (usually using hydrocone cyclone crushers) [46].

Table 4 shows the results of excavators and front-end loader activities, expressed in $\mathrm{mg} \cdot \mathrm{m}^{-3}$ [54]. Operating conditions also impact exposure values, and these differences are verifiable for both inhalable and respirable dust.

Table 4. Main results of Sepadi et al. [54] concerning equipment.

\begin{tabular}{cccc}
\hline \multirow{2}{*}{ Particle size } & Equipment & Facility & $\begin{array}{c}\text { Time-Weighted } \\
\text { Average }\end{array}$ \\
\hline \multirow{3}{*}{ Respirable dust $(<10 \mu \mathrm{m})$} & Excavator & $\mathrm{A}$ & 0.028 \\
\cline { 2 - 4 } & Front-end loader & $\mathrm{A}$ & 0.026 \\
\cline { 2 - 4 } & \multirow{2}{*}{ Excavator } & $\mathrm{A}$ & 0.022 \\
\cline { 2 - 4 } Respirable dust $(<100 \mu \mathrm{m})$ & & $\mathrm{B}$ & 0.132 \\
\cline { 2 - 4 } & Front-end loader & $\mathrm{A}$ & 0.029 \\
\hline
\end{tabular}

\subsubsection{Transport System}

Only one study analysed the possible relationship between transport system and dust concentration [28]. It was developed considering two types of transporting system: vertical wall and conventional (steps) in a limestone quarry. The main results showed that the vertical wall, a closed system, prevented most fine particles from spreading. On the contrary, in the conventional method, the dust concentration was higher (see Table 5, expressed in $\mu \mathrm{m} \cdot \mathrm{m}^{-3}$ ). It is essential to state that these results may not be time-weighted averages, as there was no information available concerning time frame.

Table 5. Relation between transport system and dust concentration [28].

\begin{tabular}{|c|c|c|c|c|c|}
\hline Monitor Site & Term & Vertical Well & Standard Deviation & Conventional System & STD \\
\hline \multirow{3}{*}{ Extraction site } & Total suspended particles & 301 & 36 & 211 & 25 \\
\hline & $\mathrm{PM}_{10}$ & 68 & 14 & 183 & 18 \\
\hline & $\mathrm{PM}_{2.5}$ & 28 & 5 & 56 & 9 \\
\hline \multirow{3}{*}{ Conveyor system } & Total suspended particles & 186 & 21 & 173 & 10 \\
\hline & $\mathrm{PM}_{10}$ & 60 & 15 & 125 & 25 \\
\hline & $\mathrm{PM}_{2.5}$ & 45 & 13 & 101 & 31 \\
\hline
\end{tabular}

\subsection{Technical Variables}

Distance

In general, there is a relationship between distance and total dust concentration [28]. As expected, the results showed that the overall dust concentration decreased with increasing distance from the source. According to two studies, this is also particularly true in relation to activities such as crushing $[8,44]$. Some authors reported that with increased distance from the exposure source, dust concentration decreased by about $89 \%$ [44]. In particular, dust concentration from drilling activities spreads up to $80-100 \mathrm{~m}$ from the source, where the heavier fractions of dust settle [44]. For this reason, some authors suggest that the proportion of fine dust tends to increase with increasing distance from the source [49], as $\mathrm{PM}_{10}$ can travel up to $100 \mathrm{~km}$ (or more) and stay in the atmosphere for days, whereas 
$\mathrm{PM}_{2.5}$ can travel as far as thousands of kilometres, staying in the air for weeks. Coarse particulates usually deposit quickly and within short distances of the source [3].

\subsection{Physical Variables}

\subsubsection{Season}

Only two studies made reference to season when assessing dust exposure [6,28], with interesting conclusions.

In one of the studies, it is reported that in the hotter seasons (spring and summer), particles are shorter due to low air humidity, as opposed to during the colder seasons (autumn and winter). This happens because the increased moisture causes suspended matter to forming larger particles. The maximum dust concentration was achieved during summer (hourly concentrations of $1100 \mu \mathrm{g} \cdot \mathrm{m}^{-3}$ ) [28], falling outside of the average concentration range of $600-820 \mu \mathrm{m} \cdot \mathrm{m}^{-3}$. Conversely, other studies observed that both $\mathrm{PM}_{2.5}$ and $\mathrm{PM}_{10}$ concentrations were higher during winter [6]. However, this was attributable, according to the authors, to the prevalence of anticyclonic conditions.

The influence of season is, for obvious reasons, related to weather conditions, which will be discussed in the following section.

\subsubsection{Weather}

Dust concentration related to weather was referred to in two studies $[28,44]$.

Dust concentration has an almost linear relation with wind speed at a measurement point at $300 \mathrm{~m}$ from the extraction outline [28]. Additionally, it was verified that the aerosol concentration increased with increasing wind speed, despite decreasing with increased humidity. This latter fact occurs due increasing particle size (as a result of combination with water), leading to easier deposition. The other study mentioned that dust concentrates the downwind, and upwind of the source, there is no significant dust concentration [44]. Interestingly, it was reported that particles moving in the downward direction (within the pit) take longer to escape from the zone, which increases the duration exposure to dust, meaning that attention should be paid to the behaviour of particles [45]. It is also stated that villages in downwind locations can suffer from traveling particles [55].

\subsection{Other Variables}

Interestingly, one study reported and analysed workers' respiratory symptoms, and $49.1 \%$ of total workers were found suffered from phlegm, $42.9 \%$ from breathlessness, and $37.5 \%$ from a cough. Despite the fact that exposure to dust remained below the maximum exposure value, these workers showed a high prevalence of respiratory symptoms [50].

The relationship between dust exposure and other variables, such as air humidity or wind velocity, is complex and cannot be summarised in this analysis, our analysis was carried out case by case, and the relationship itself is not entirely clear. Despite gathering data regarding weather parameters, could be proposed. However, the risk of exposure depends on, among other factors, the characteristics of the dust, activity, duration of exposure, characteristics of workers, and use of personal protective equipment $[46,54]$. Notwithstanding the results, particular attention should be continuously paid to this issue because exposure, in the long term, may impair the health of workers [53].

\subsection{Bias}

Risk of bias [38] (Table 6) was assessed at the study level. Papers were analysed according to methodology (task definition, equipment type, standard application, measurement precision, sampling time, sample representativeness, and equipment calibration), and other factors (reporting quality and reference quality). The possibility of each parameter having impacted on the outcome, therefore representing some type of bias, was determined using one of the classifications [38]: "high risk", "low risk", and "unclear risk". Notwithstanding that the experimental protocols were well-defined, primarily regarding task definition, no information about equipment calibration or measurement precision was provided. It is 
important to note that this assessment is subjective and depends on the information reported in each study. Whenever the required piece of information is clearly stated in the text, the classification is more or less direct, according to the suitability of its methods (for instance, if the used equipment was appropriate for the study's needs). In cases of no information, it is not possible to infer a relationship. When the methodology is not appropriate or the results (obtained by the studies) do not align with the methodology, risk of bias is elevated.

Table 6. Bias analysis of each study.

\begin{tabular}{|c|c|c|c|c|c|c|c|c|c|}
\hline \multirow[b]{2}{*}{ Study } & \multicolumn{7}{|c|}{ Methodology } & \multicolumn{2}{|c|}{ Other } \\
\hline & $\begin{array}{c}\text { Task } \\
\text { Definition }\end{array}$ & $\begin{array}{l}\text { Equipment } \\
\text { Type }\end{array}$ & $\begin{array}{l}\text { Standard } \\
\text { Application }\end{array}$ & $\begin{array}{c}\text { Measurement } \\
\text { Precision }\end{array}$ & $\begin{array}{c}\text { Sampling } \\
\text { Time }\end{array}$ & $\begin{array}{l}\text { Sampling } \\
\text { Represen- } \\
\text { tativeness }\end{array}$ & $\begin{array}{l}\text { Equipment } \\
\text { Calibration }\end{array}$ & $\begin{array}{c}\text { Reporting } \\
\text { Quality }\end{array}$ & $\begin{array}{c}\text { References } \\
\text { Quality }\end{array}$ \\
\hline [28] & LR & LR & HR & UR & HR & HR & HR & LR & HR \\
\hline [31] & HR & LR & LR & UR & LR & LR & HR & LR & HR \\
\hline [41] & LR & LR & HR & UR & HR & HR & HR & LR & HR \\
\hline [42] & HR & LR & LR & UR & UR & UR & LR & HR & HR \\
\hline [43] & LR & LR & HR & UR & UR & UR & LR & LR & LR \\
\hline [44] & LR & LR & HR & UR & HR & HR & HR & LR & HR \\
\hline [45] & LR & LR & HR & UR & HR & UR & HR & LR & LR \\
\hline [46] & LR & LR & LR & UR & LR & UR & LR & LR & LR \\
\hline [47] & LR & LR & LR & UR & UR & UR & LR & LR & HR \\
\hline [30] & LR & LR & LR & UR & UR & UR & LR & LR & LR \\
\hline [48] & HR & UR & HR & UR & UR & UR & HR & HR & LR \\
\hline [49] & LR & LR & HR & UR & UR & UR & LR & LR & LR \\
\hline [50] & LR & LR & HR & UR & LR & UR & LR & LR & LR \\
\hline [25] & LR & LR & HR & UR & LR & LR & HR & LR & LR \\
\hline [51] & LR & LR & HR & UR & HR & LR & HR & LR & LR \\
\hline [6] & LR & LR & LR & UR & LR & UR & HR & LR & LR \\
\hline [52] & LR & LR & HR & UR & LR & UR & HR & LR & LR \\
\hline [9] & HR & UR & LR & UR & LR & HR & HR & LR & LR \\
\hline [53] & LR & LR & LR & UR & LR & UR & HR & LR & HR \\
\hline [8] & LR & LR & HR & UR & HR & LR & HR & LR & LR \\
\hline [32] & LR & LR & LR & UR & HR & LR & LR & LR & LR \\
\hline [54] & LR & LR & LR & UR & LR & LR & LR & LR & HR \\
\hline [55] & LR & UR & HR & UR & LR & LR & HR & LR & HR \\
\hline [56] & HR & HR & HR & HR & HR & HR & HR & HR & HR \\
\hline
\end{tabular}

HR: high risk; LR: low risk; UR: unclear risk.

With the exception of equipment type, every other variable in the Methodology section demonstrates the necessity of improving reporting quality concerning the applied experimental protocols.

\subsection{Study Limitations}

One of the main limitations of this study is that the collected data could not be compared due to a lack of specificity of the studies concerning aims, applied protocol, and presentation of results. This led to a paper-by-paper analysis that does not provide a general view on the topic, making it difficult to standardise design solutions. The idea of using a common standardised protocol is stressed in the literature [57]. Additionally, it was not possible to infer whether the culture of each country influenced practices. For instance, it is mentioned in one of the studies that although remaining below the national standard, 
the dust exposure was way above international standards [41]. Uncertainties related to exposure assessment may influence risk-management practices, which may, in turn, negatively impact the health of workers [58]. Overall, it was impossible to determine the extent to which the results of the reviewed studies truly represent real-life working conditions. Therefore, this scoping review mainly supports the need to apply or develop standardised protocols concerning information, such as that reflected in Table 6.

\section{Conclusions}

Air pollution is a growing issue worldwide, and dust emission from anthropogenic activities affects not only directly exposed workers but also surrounding communities [1]. Dust is produced in almost every mining activity and similar tasks, such as road construction and earthmoving tasks [16]. Common dust-control strategies include spraying water, although other mechanisms are starting to be developed, such as ultrasonic suppression systems [30]. Despite significant downward trends in exposure to respirable quartz and respirable silica, according to a recent assessment [59], deaths associated with this issue still occur, with a special focus on pneumoconiosis [60]. Some authors suggest that highrisk workers need training in use of personal protective equipment and that dust-control mechanisms are still far from what they need to be [30]. The aim of this scoping review was to determine the specific circumstances under which exposure to dust occurs within the context of open-pit mining and quarrying, including research from other fields with similar tasks, such as road construction and earthworks and identifying measures to mitigate or even eliminate dust production. Within the reviewed studies, it was possible to identify the following variables related to dust exposure: job-related (activity, job category, and site), engineering (equipment, transport system), technical (distance), and physical (season and weather) variables. However, the significant variance in protocol settings made it difficult to perform any general analysis, resulting in a study-by-study approach. Despite this, data were grouped by assessed variable (whenever possible). Results showed that drilling was often pointed to as a task leading to higher levels of dust exposure $[41,53]$, although every activity related to rock processing (blasting and loading, for instance) also had a positive association with high dust levels [53]. Workers performing their job inside climatised vehicles experienced less exposure to dust [50] than workers whose work leads directly to dust generation [32].

Notwithstanding the task, it was reported in one study that the size of the particles was below $10 \mu \mathrm{m}$ [30]. The face of operation where most work occurs was naturally the site where the highest dust levels were measured. One study addressed particle travel time and concluded that mine geometry is an important factor reflecting occupational exposure [45]. Few types of equipment were mentioned related to dust exposure: drill, crusher, truck, excavator, and loader. Concerning this variable, the focus was on the setting; for example, trucks travelling on unpaved roads were associated with high dust levels [43]. Other specific assumptions were described but not in a way constituting data. Transport system was analysed in just one of the studies and only compared two methodologies [28]. Therefore, no general conventions can be drawn. According to the same author, dust concentration decreased with increased distance from the source, and this was also verified in other contexts $[44,49]$. Season as a variable was acknowledged with relation to moisture or rain, which depend on weather and specific factors, such as wind direction and humidity. Concerning mitigating measures, none of the studies analysed potential mechanisms for solving this problem.

\section{Practical Implications}

This scoping review highlights the necessity of adopting standard procedures for data collection, independent of research objective. It is mentioned in the literature that this process is quite demanding, as it is conditioned by each specific setting, which, as a standalone condition, already makes it difficult to properly apply in the protocol [8].

Nonetheless, with the collected data, one study suggests the following steps [58]: 
(1) A comprehensive description of the occupational setting;

(2) Analysis of the mineralogical characteristics of the hazardous agent;

(3) Measurement of the exposure to respirable dust, according to international standards, in the workers' breathing zone during a full shift.

Although these steps seem achievable, they are not applied often. The same author also states that it is important to preserve historical data so that a database can be organised that can help determine more strategic actions concerning the health and safety of both workers and operations.

Author Contributions: Conceptualization, J.D., J.C.B., and J.S.B.; methodology, J.D.; validation, J.C.B., F.R., M.V., and J.S.B.; formal analysis, J.D.; investigation, J.D., J.C.B., F.R., M.V., and J.S.B.; writingoriginal draft preparation, J.D.; writing-review and editing, J.C.B., F.R., M.V., and J.S.B.; supervision, J.C.B. and J.S.B.; project administration, J.C.B., F.R., and J.S.B.; funding acquisition, J.D. All authors have read and agreed to the published version of the manuscript.

Funding: This work was supported by Fundação para a Ciência e a Tecnologia (FCT) through INEGI, under LAETA (PROA) project SFRH/BD/143241/2019. The authors would also like to acknowledge the Doctoral Program in Occupational Safety and Health from the Faculty of Engineering of the University of Porto for the funding.

Institutional Review Board Statement: Not applicable.

Informed Consent Statement: Not applicable.

Data Availability Statement: Not applicable.

Conflicts of Interest: The authors declare no conflict of interest. 


\section{Appendix A}

Table A1. Paper-related data, general information, and people-related data of each study.

\begin{tabular}{|c|c|c|c|c|c|c|c|c|c|c|}
\hline \multicolumn{2}{|r|}{ Paper-Related Data } & \multicolumn{4}{|c|}{ General Information } & \multicolumn{5}{|c|}{ People-Related Data } \\
\hline Study & Objective & Substance & Time Period & $\begin{array}{l}\text { Ethical } \\
\text { Committee }\end{array}$ & $\begin{array}{c}\text { Informed } \\
\text { Consent }\end{array}$ & Population & Sample & $\begin{array}{c}\text { Age } \\
\text { (Years) }\end{array}$ & Sex & $\begin{array}{l}\text { Control } \\
\text { Group }\end{array}$ \\
\hline [28] & $\begin{array}{l}\text { To characterise dust emission and } \\
\text { to identify locations of pollution } \\
\text { sources }\end{array}$ & $\begin{array}{l}\text { Dust (TSP, } \mathrm{PM}_{2.5} \\
\left.\quad \mathrm{PM}_{10}\right)\end{array}$ & NM & NA & NA & NM & NM & NM & NM & NM \\
\hline$[31]$ & $\begin{array}{l}\text { To characterise dust generated } \\
\text { from haul trucks }\end{array}$ & Dust $\left(\mathrm{PM}_{10},\right)$ & Summer of 2002 & NM & NM & NM & NM & NM & NM & $\mathrm{NM}$ \\
\hline [41] & $\begin{array}{c}\text { To assess occupational exposure } \\
\text { to dust }\end{array}$ & $\begin{array}{l}\text { Dust (respirable), } \\
\text { silica }\end{array}$ & 1994-2005 & NA & NA & NM & NM & NM & NM & NM \\
\hline [42] & To determine dust concentrations & $\begin{array}{l}\text { Dust (respirable, } \\
\text { inhalable) }\end{array}$ & NM & NM & NM & NM & NM & NM & $\mathrm{NM}$ & NM \\
\hline [43] & $\begin{array}{l}\text { To estimate annual emissions } \\
\text { from construction work }\end{array}$ & $\begin{array}{l}\text { Dust }\left(\mathrm{PM}_{1}, \mathrm{PM}_{2.5}\right. \\
\left.\quad \mathrm{PM}_{10}\right) \\
\end{array}$ & $\begin{array}{l}\text { Earthworks: } 3 \text { days, } \\
\text { road construction: } 3 \text { days }\end{array}$ & NA & NA & NA & NA & NA & NA & NA \\
\hline [44] & $\begin{array}{l}\text { To develop models to predict } \\
\text { respirable dust-particle } \\
\text { concentration }\end{array}$ & Dust $\left(\mathrm{PM}_{2.5}, \mathrm{PM}_{10}\right)$ & Pre-summer, summer and winter & NM & NM & NM & NM & NM & NM & NM \\
\hline [45] & $\begin{array}{l}\text { To investigate particulate-matter } \\
\text { concentration profiles }\end{array}$ & $\begin{array}{l}\text { Dust (PM 10-20 } \mu \mathrm{m}, \\
4-10 \mu \mathrm{m}, \text { and }<4 \mu \mathrm{m})\end{array}$ & $\begin{array}{c}\text { 21-23 May } 2013 \text { (Location 1), } \\
\text { 4-6 June } 2013 \text { (Location 2), } \\
\text { 12-24 October } 2013 \text { (Location 3) }\end{array}$ & NM & NM & NM & NM & NM & NM & NM \\
\hline [46] & $\begin{array}{l}\text { To determine exposure levels to } \\
\text { respirable dust and respirable } \\
\text { crystalline silica of } \\
\text { crusher operators }\end{array}$ & Dust, quartz & NM & Yes & NM & 200 & 70 & NM & $\mathrm{NM}$ & NM \\
\hline [47] & $\begin{array}{l}\text { To assess levels of exposure to } \\
\text { respirable dust and } \\
\text { respirable silica }\end{array}$ & $\begin{array}{l}\text { Dust (respirable), } \\
\text { silica (respirable) }\end{array}$ & $\begin{array}{l}\text { Mine 1: January-April 2010; Mine 2: } \\
\text { November 2010-February 2011; Mine } \\
\text { 3: February-May 2011; Mine 4 June } \\
\text { 2010; Mine 5: July-September 2010; } \\
\text { Mine 6: October } 2010\end{array}$ & Yes & Yes & NM & 232 & NM & NM & NM \\
\hline$[30]$ & $\begin{array}{l}\text { To characterise exposure to } \\
\text { respirable dust }\end{array}$ & Dust, quartz & 2012-2014 & NM & NM & NM & 69 & NM & NM & NM \\
\hline [48] & $\begin{array}{l}\text { To study occupational health } \\
\text { exposure to physical and } \\
\text { chemical hazards }\end{array}$ & Dust $\left(\mathrm{PM}_{10}\right)$ & NM & NA & NA & NM & NM & NM & NM & NM \\
\hline
\end{tabular}


Table A1. Cont.

\begin{tabular}{|c|c|c|c|c|c|c|c|c|c|c|}
\hline \multicolumn{2}{|r|}{ Paper-Related Data } & \multicolumn{4}{|c|}{ General Information } & \multicolumn{5}{|c|}{ People-Related Data } \\
\hline Study & Objective & Substance & Time Period & $\begin{array}{l}\text { Ethical } \\
\text { Committee }\end{array}$ & $\begin{array}{c}\text { Informed } \\
\text { Consent }\end{array}$ & Population & Sample & $\begin{array}{c}\text { Age } \\
\text { (Years) }\end{array}$ & Sex & $\begin{array}{l}\text { Control } \\
\text { Group }\end{array}$ \\
\hline [49] & To study particulate emission & $\begin{array}{c}\text { Dust }\left(\mathrm{PM}_{2.5}\right. \\
\left.\text { PM } 0.3-20 \mu \mathrm{m}, \mathrm{PM}_{10}\right) \\
\end{array}$ & NM & NA & NA & NA & NA & NA & NA & NA \\
\hline$[50]$ & $\begin{array}{c}\text { To study respiratory impairment } \\
\text { and personal respirable exposure } \\
\text { to dust }\end{array}$ & Dust & NM & NM & Yes & NM & 112 & $21-60$ & $\begin{array}{l}\text { Male, } \\
\text { female }\end{array}$ & NM \\
\hline$[25]$ & $\begin{array}{l}\text { To study inhalable, thoracic, } \\
\text { and alveoli particle concentrations }\end{array}$ & $\begin{array}{l}\text { Dust (PM 10-20 } \mu \mathrm{m}, \\
4-10 \mu \mathrm{m}, \text { and }<4 \mu \mathrm{m})\end{array}$ & Winter & NA & NA & NA & NA & NA & NA & NA \\
\hline$[51]$ & $\begin{array}{l}\text { To study dust emission (and } \\
\text { dispersion) from drilling in } \\
\text { natural stone quarries }\end{array}$ & $\begin{array}{l}\text { Dust (TSP, } \mathrm{PM}_{1} \\
\left.\mathrm{PM}_{2.5}, \mathrm{PM}_{10}\right)\end{array}$ & Winter & NM & NM & NM & NM & NM & NM & NM \\
\hline$[6]$ & NM & Dust $\left(\mathrm{PM}_{2.5}, \mathrm{PM}_{10}\right)$ & Summer and winter 2015-2016 & NA & NA & NA & NA & NA & NA & NA \\
\hline [52] & $\begin{array}{l}\text { To study the concentration and } \\
\text { distribution of } \mathrm{PM}_{2.5} \text { and } \mathrm{PM}_{10} \text { in } \\
\text { open-pit mines }\end{array}$ & Dust $\left(\mathrm{PM}_{2.5}, \mathrm{PM}_{10}\right)$ & NM & NA & NA & NA & NA & NA & NA & NA \\
\hline [9] & $\begin{array}{l}\text { To predict dust concentrations } \\
\text { from several mine operations }\end{array}$ & Dust $\left(\mathrm{PM}_{2.5}, \mathrm{PM}_{10}\right)$ & $\begin{array}{c}\text { 7-22 December 2015, } 30 \text { January to } \\
16 \text { February } 2016\end{array}$ & NA & NA & NA & NA & NA & NA & NA \\
\hline [8] & $\begin{array}{l}\text { To study dust emission (and } \\
\text { dispersion) from crushing in } \\
\text { open-pit quarries }\end{array}$ & $\begin{array}{l}\text { Dust (TSP, } \mathrm{PM}_{1} \\
\left.\mathrm{PM}_{2.5}, \mathrm{PM}_{10}\right)\end{array}$ & Winter & NA & NA & NM & NM & NM & NM & NM \\
\hline [32] & $\begin{array}{l}\text { To study exposure levels at } \\
\text { four workplaces }\end{array}$ & Dust & August 2016-October 2016 & NM & NM & NM & NM & NM & NM & NM \\
\hline [54] & $\begin{array}{l}\text { To study dust-exposure risk at } \\
\text { two wasterock crusher plants }\end{array}$ & $\begin{array}{l}\text { Dust (inhalable and } \\
\text { respirable) }\end{array}$ & October 2018 & NM & NM & 100 & 34 & $\begin{array}{l}37 \text { years } \\
\text { (range } \\
23 \text { to } \\
68 \text { years) }\end{array}$ & $\begin{array}{l}\text { Male, } \\
\text { female }\end{array}$ & NM \\
\hline [55] & $\begin{array}{l}\text { To study emission of respirable } \\
\text { dust from stone quarrying, } \\
\text { potential health effects, } \\
\text { and its management }\end{array}$ & $\begin{array}{l}\text { Dust }\left(\mathrm{PM}_{2.5} \text { and }\right. \\
\mathrm{PM}_{10}\end{array}$ & June 2019 & NA & NA & NA & NA & NA & NA & NA \\
\hline$[56]$ & $\begin{array}{l}\text { To evaluate potential dust } \\
\text { emissions in an open-pit coal mine }\end{array}$ & $\begin{array}{l}\text { Dust }\left(\mathrm{PM}_{2.5}, \mathrm{PM}_{4}\right. \\
\left.\mathrm{PM}_{10}\right)\end{array}$ & NM & NA & NA & NA & NA & NA & NA & NA \\
\hline
\end{tabular}


Table A2. Occupational exposure characterisation per study.

\begin{tabular}{|c|c|c|c|c|c|c|c|c|}
\hline \multirow[b]{2}{*}{ Study } & \multicolumn{8}{|c|}{ Occupational Exposure } \\
\hline & Standards & $\begin{array}{l}\text { Duration of the } \\
\text { Occupational } \\
\text { Exposure }\end{array}$ & Source of Exposure & Methodology & Measuring Equipment & $\begin{array}{l}\text { Equipment } \\
\text { Calibration }\end{array}$ & $\begin{array}{l}\text { Sampling } \\
\text { Time }\end{array}$ & $\begin{array}{l}\text { Sampling } \\
\text { Frequency }\end{array}$ \\
\hline [28] & NM & NM & NM & $\begin{array}{c}\text { Dust was collected at different distances: } 0.05,0.08 \text {, } \\
0.1,0.15,0.2,0.3,0.4,1,7,10,11 \text {, and } 15 \mathrm{~km} \text { from } \\
\text { the extraction outline. Additionally, five more } \\
\text { monitoring stations were considered. The particle } \\
\text { sizes were determined, and dust composition was } \\
\text { analysed through chromatography. }\end{array}$ & $\begin{array}{l}\text { Graseby high-volume sampler } \\
\text { (GM-2000), Kimoto } \mathrm{PM}_{10}\end{array}$ & NM & $1 \mathrm{~h}$ & $\begin{array}{l}3 \text { times per } \\
\text { season and at } \\
\text { each receptor }\end{array}$ \\
\hline [41] & NM & NM & $\begin{array}{c}\text { Overburden loading, } \\
\text { stockyard, coal loading, } \\
\text { drilling, } \\
\text { and coal-handling plant }\end{array}$ & $\begin{array}{l}\text { Data were collected from the Can Lignite } \\
\text { Corporation once a year at five different locations. } \\
\text { Dust conditions were assessed, and dust samples } \\
\text { were dried and weighed. Additionally, silica } \\
\text { content was determined. An ANOVA statistical } \\
\text { test was used for data treatment. }\end{array}$ & $\begin{array}{l}\text { Gravimetric dust equipment } \\
\text { (Casella AFC 123), infrared } \\
\text { spectrophotometer }\end{array}$ & NM & $4 \mathrm{~h}$ & 1 per year \\
\hline [42] & NIOSH 7500 & NM & $\begin{array}{l}\text { Mountain slash, crusher, } \\
\text { administration, road }\end{array}$ & $\begin{array}{l}\text { Samples of total and respirable dust were collected } \\
\text { by the gravimetric method. The number of } \\
\text { collected samples was } 19 \text { for mountain slash } \\
\text { (excavation), } 19 \text { for various crushers, } 9 \text { for } \\
\text { administration, and } 5 \text { for road. SPSS was used for } \\
\text { data treatment. }\end{array}$ & Sampling pump (SKC) & NM & NM & NM \\
\hline [43] & NM & NA & Earthworks, equipment & $\begin{array}{l}\text { All measurements were performed between } 20 \text { and } \\
60 \text { m downwind of the sites. Measurements were } \\
\text { taken at a height of } 4 \mathrm{~m} \text {. Overall meteorological } \\
\text { data were also collected, as well as trace gases } \\
\left(\mathrm{NOx}, \mathrm{CO}, \mathrm{SO}_{2}, \mathrm{O}_{3} \text {, and } \mathrm{CO}_{2}\right) \text {. Total particulate } \\
\text { polycyclic aromatic hydrocarbon (p-PAH) mass } \\
\text { concentration was recorded. Particle size } \\
\text { distributions were analysed by a fast-mobility } \\
\text { particle-sizer spectrometer (FMPSS) and an optical } \\
\text { particle counter (OPC). }\end{array}$ & $\begin{array}{l}\text { Mobile aerosol research } \\
\text { laboratory (MoLA), weather } \\
\text { station (WXT520), air quality } \\
\text { monitoring system (Airpointer } \\
\text { and LI840), FMPSS (Model } \\
\text { 3091), OPC (Grimm } \\
\text { Aerosoltechnik) }\end{array}$ & Yes & NM & NM \\
\hline
\end{tabular}


Table A2. Cont.

\begin{tabular}{|c|c|c|c|c|c|c|c|c|}
\hline \multirow[b]{2}{*}{ Study } & \multicolumn{8}{|c|}{ Occupational Exposure } \\
\hline & Standards & $\begin{array}{l}\text { Duration of the } \\
\text { Occupational } \\
\text { Exposure }\end{array}$ & Source of Exposure & Methodology & Measuring Equipment & $\begin{array}{l}\text { Equipment } \\
\text { Calibration }\end{array}$ & $\begin{array}{l}\text { Sampling } \\
\text { Time }\end{array}$ & $\begin{array}{l}\text { Sampling } \\
\text { Frequency }\end{array}$ \\
\hline [44] & NM & NM & Drilling & $\begin{array}{l}\text { Measurements were collected at different distances } \\
\text { from the drilling site, considering different wind } \\
\text { directions in three phases: (1) pre-summer, (2) } \\
\text { during summer, (3) during winter. Monitoring of } \\
\text { air quality was carried out, and both this parameter } \\
\text { and dust emission were registered at different } \\
\text { distances from the drilling operations, } \\
\text { with different wind directions. }\end{array}$ & $\begin{array}{l}\text { Personal dust monitor (5), } \\
\text { point sampler (2), } \\
\text { meteorological monitoring } \\
\text { station }\end{array}$ & NM & $1 \mathrm{~h}$ & Hourly basis \\
\hline [45] & NM & NM & $\begin{array}{l}\text { Drilling, excavation, } \\
\text { loading, transport }\end{array}$ & $\begin{array}{l}\text { Measurements were taken at different benches } \\
\text { (heights) of the open casts, Malanjkhand Copper } \\
\text { Project (MCP), Kiriburu Iron OreMine (KIOM), } \\
\text { and Meghahatuburu Iron Ore Mine (MIOM). } \\
\text { Wind speed and wind direction were also } \\
\text { registered. In MCP, the activities were drilling, } \\
\text { excavation, loading (shovel), and transport } \\
\text { (dumper). Sampling occurred at four benches } \\
\text { located at 412, 448, } 460 \text {, and } 580 \text { mRL. In KIOM, } \\
\text { these sampling points were located at } 818 \mathrm{mRL} \text {, } \\
\text { and in MIOM, the sampling points were at } \\
846 \mathrm{mRL} \text {. }\end{array}$ & $\begin{array}{l}\text { Portable aerosol spectrometer } \\
\text { (model 1.108), portable weather } \\
\text { stations (Watch Dog } \\
2000 \text { Series) }\end{array}$ & NM & $30 \mathrm{~min}$ & $1 \mathrm{~min}$ \\
\hline [46] & $\begin{array}{l}\text { NIOSH Manual } \\
\text { Analytical } \\
\text { Method No. } \\
0600\end{array}$ & NM & Crusher & $\begin{array}{l}\text { Long-term personal breathing-zone samples were } \\
\text { collected for each shift. Air velocity and humidity } \\
\text { were also measured to determine temperature and } \\
\text { humidity during the field campaign. These } \\
\text { measurements were taken at several locations, } \\
\text { during the morning and afternoon. The samples } \\
\text { were analysed at an independent laboratory. } \\
\text { Data analysis was carried out using Industrial } \\
\text { Hygiene Statistic (IH STAT V. 235). }\end{array}$ & $\begin{array}{l}\text { Sampling pump (SKC), } \\
\text { anemometer and hygrometer } \\
\text { (TSI, 8386-M-GB) }\end{array}$ & Yes & $8 \mathrm{~h}$ & NM \\
\hline [47] & $\begin{array}{l}\text { NIOSH 0600, } \\
\text { NIOSH } 7500\end{array}$ & NM & $\begin{array}{c}\text { Mining, crushing, } \\
\text { concentrating, } \\
\text { pelletising, mobile shop, } \\
\text { stationery shop, } \\
\text { office/control }\end{array}$ & $\begin{array}{l}\text { Each worker wore a personal air-sampling pump } \\
\text { on the waist, with the sampler located in the } \\
\text { breathing zone for } 70 \% \text { of their work shift. For each } \\
\text { worker, the study was conducted during three } \\
\text { different shifts, and one blank sample per day was } \\
\text { also collected (quality control). The data received } \\
\text { statistical treatment through ANOVA analysis. } \\
\text { The information was grouped in SEG form. }\end{array}$ & $\begin{array}{l}\text { Personal air-sampling pump } \\
\text { (Apex Pro pump, Casella) }\end{array}$ & Yes & NM & NM \\
\hline
\end{tabular}


Table A2. Cont.

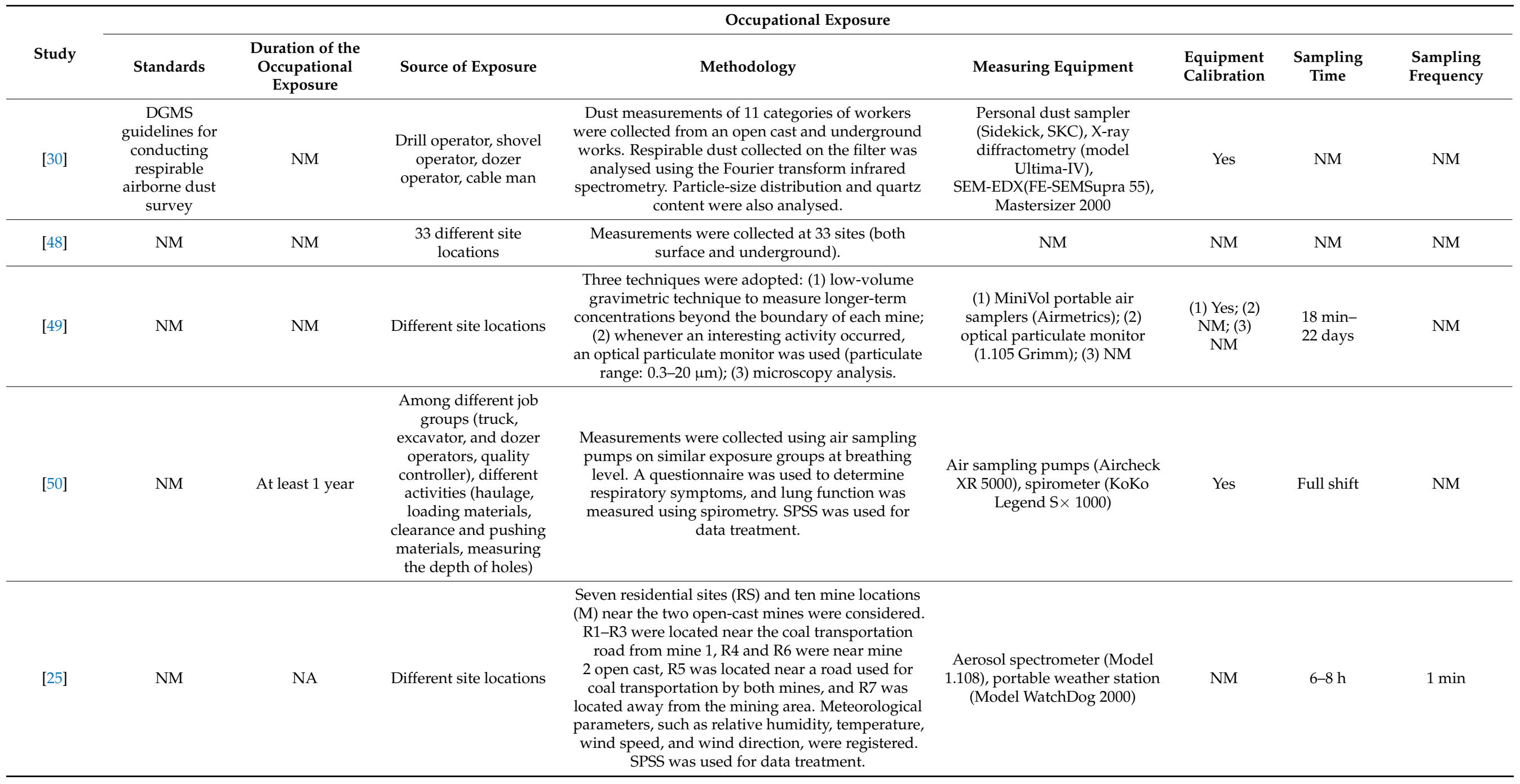


Table A2. Cont.

\begin{tabular}{|c|c|c|c|c|c|c|c|c|}
\hline \multirow[b]{2}{*}{ Study } & \multicolumn{8}{|c|}{ Occupational Exposure } \\
\hline & Standards & $\begin{array}{l}\text { Duration of the } \\
\text { Occupational } \\
\text { Exposure }\end{array}$ & Source of Exposure & Methodology & Measuring Equipment & $\begin{array}{l}\text { Equipment } \\
\text { Calibration }\end{array}$ & $\begin{array}{l}\text { Sampling } \\
\text { Time }\end{array}$ & $\begin{array}{l}\text { Sampling } \\
\text { Frequency }\end{array}$ \\
\hline [51] & NM & NM & Drilling & $\begin{array}{l}\text { Dust mass concentrations measurements were } \\
\text { collected near the drills and at the same level at } \\
\text { different distances downwind, upwind, } \\
\text { and side-wind. The sampling height was } 1.5 \mathrm{~m} \\
\text { (approximately breathing level). Weather data, } \\
\text { such as temperature, humidity, absolute and } \\
\text { relative pressure, wind speed and direction, } \\
\text { wind-gust speed, and rainfall, were also registered. }\end{array}$ & $\begin{array}{l}\text { Nephelometers (Turnkey } \\
\text { Osiris), weather station } \\
\text { (EasyWeather) }\end{array}$ & NM & $15 \mathrm{~min}$ & $5 \mathrm{~s}$ \\
\hline [6] & $\begin{array}{c}\text { National } \\
\text { Ambient Air } \\
\text { Quality } \\
\text { Standard } \\
\text { (NAAQS 2009), } \\
\text { I.S.: } 5182 \text { Part } \\
\text { XIV (2000) }\end{array}$ & NA & Different site locations & $\begin{array}{l}\text { Measurements were collected from eight } \\
\text { monitoring stations. } \mathrm{PM}_{10} \text { and } \mathrm{PM}_{2.5} \\
\text { concentrations were calculated based on the } \\
\text { differences in the weight of the filters before and } \\
\text { after sampling. }\end{array}$ & $\begin{array}{c}\text { Respirable dust samplers } \\
\text { (Envirotech APM 460 NL and } \\
\text { Envirotech APM 550) }\end{array}$ & NM & $24 \mathrm{~h}$ & NM \\
\hline [52] & NM & NM & $\begin{array}{l}\text { Mining, transportation, } \\
\text { dumping }\end{array}$ & $\begin{array}{l}\text { PM measurements were monitored at three sites in } \\
\text { the mine: (1) in the pit, away from the operating } \\
\text { equipment; (2) near the mining and transport } \\
\text { equipment; (3) around the pit. The data received } \\
\text { statistical treatment. }\end{array}$ & Beta-ray particle monitor & NM & NM & $1 \mathrm{~min}$ \\
\hline [9] & $\begin{array}{l}\text { National } \\
\text { Ambient Air } \\
\text { Quality } \\
\text { Standard } \\
\text { (NAAQS) }\end{array}$ & NA & Different site locations & $\begin{array}{l}\text { Measurements of baseline air quality were } \\
\text { monitored at } 25 \text { different station locations. } \\
\text { The resulting data were used to develop } \\
\text { emission models. }\end{array}$ & NM & NM & $24 \mathrm{~h}$ & NM \\
\hline$[53]$ & $\begin{array}{l}\text { DGMS } \\
\text { sampling } \\
\text { guidelines }\end{array}$ & NM & $\begin{array}{c}\text { Different site locations, } \\
\text { activity }\end{array}$ & $\begin{array}{l}\text { Measurement of respirable dust and determination } \\
\text { of free silica content: } 12 \text { dust samples were } \\
\text { collected in September } 2013 \text { (five area samples and } \\
\text { seven personal samples). Another } 12 \text { were } \\
\text { collected in February } 2014 \text { (six area samples and six } \\
\text { individual samples). The equipment was placed } \\
\text { between 5-15 m away from the worker for area } \\
\text { sampling, at breathing level height. For personal } \\
\text { sampling, the equipment was attached to the } \\
\text { worker for an entire shift. Silica estimation was } \\
\text { carried out through the Fourier transform infrared } \\
\text { (FTIR) spectroscopy. }\end{array}$ & $\begin{array}{l}\text { Personal dust sampler } \\
\quad \text { (Sidekick 51Ex) }\end{array}$ & Yes & $\begin{array}{l}\text { 6-7 h per } \\
\text { day }\end{array}$ & NM \\
\hline
\end{tabular}


Table A2. Cont.

\begin{tabular}{|c|c|c|c|c|c|c|c|c|}
\hline \multirow[b]{2}{*}{ Study } & \multicolumn{8}{|c|}{ Occupational Exposure } \\
\hline & Standards & $\begin{array}{l}\text { Duration of the } \\
\text { Occupational } \\
\text { Exposure }\end{array}$ & Source of Exposure & Methodology & Measuring Equipment & $\begin{array}{l}\text { Equipment } \\
\text { Calibration }\end{array}$ & $\begin{array}{c}\text { Sampling } \\
\text { Time }\end{array}$ & $\begin{array}{l}\text { Sampling } \\
\text { Frequency }\end{array}$ \\
\hline [8] & NM & NA & Crushing & $\begin{array}{l}\text { Measurements were taken at different distances } \\
\text { from the crushers, from downwind, upwind, } \\
\text { and crosswind. The setup was conducted under } \\
\text { real conditions and at crusher level during daylight. } \\
\text { Background concentrations were collected at each } \\
\text { quarry during the night. }\end{array}$ & $\begin{array}{l}\text { Nephelometers (Turnkey } \\
\text { Osiris), weather station } \\
\text { (EasyWeather) }\end{array}$ & NM & $15 \mathrm{~min}$ & $5 \mathrm{~s}$ \\
\hline [54] & NIOSH 7602 & $\begin{array}{l}\text { Facility A: } \\
36.8 \text { years old, } \\
\text { Facility B: } \\
36.9 \text { years old }\end{array}$ & $\begin{array}{l}\text { Crusher plant: crushing, } \\
\text { loading, offloading, } \\
\text { screening, final storage, } \\
\text { transporting, cleaning, } \\
\text { water sprayer, diesel } \\
\text { attendant, } \\
\text { supervising/foreman, } \\
\text { weighing bridge, } \\
\text { welding }\end{array}$ & $\begin{array}{l}\text { The protocol was divided into three parts: }(1) \\
\text { walkthrough observation, (2) self-administered } \\
\text { questionnaire, (3) static dust sampling (18 dust } \\
\text { samples: nine inhalable and nine respirable). } \\
\text { Statistical analysis was carried out. }\end{array}$ & $\begin{array}{c}\text { Multi-fraction Institute of } \\
\text { Occupational Medicine (IOM) } \\
\text { samplers }\end{array}$ & Yes & $8 \mathrm{~h}$ & NM \\
\hline [55] & NM & NA & $\begin{array}{l}\text { Haul road, crushing } \\
\text { area, pit area }\end{array}$ & $\begin{array}{l}\text { Samples were collected from four locations. } \\
\text { Ambient temperature, wind speed, humidity, } \\
\text { and dominant wind direction were also registered. } \\
\text { The instrument was placed at a height of } 1.5 \mathrm{~m} \\
\text { from the ground. }\end{array}$ & $\begin{array}{c}\text { Portable microprocessor-based } \\
\text { particulate monitor } \\
\text { (HAZDUST-EPAM } 5000 \text { model) }\end{array}$ & NM & $1 \mathrm{~h}$ & $60 \mathrm{~s}$ \\
\hline [56] & $\begin{array}{l}\text { ISO-589, 1981, } \\
\text { ISO-1171, 1976, } \\
\text { ISO-562, 1974, } \\
\text { ASTM D-3286, } \\
\text { D-3302M, } \\
\text { D3174-12 }\end{array}$ & NA & $\begin{array}{l}\text { Coal-working fronts, } \\
\text { tailings-handling sites, } \\
\text { road-traffic sites }\end{array}$ & $\begin{array}{l}\text { Samples of deposited dust were collected in trays } \\
\text { left at each location for } 30 \text { min until reaching } \\
200-500 \mathrm{~g} \text {. Passive stubs were also used for } 1 \mathrm{~h} \text {. } \\
\text { After, they were analysed for particle size and } \\
\text { geochemical and mineralogical patterns. } \\
\text { Additionally, online measurements of ambient air } \\
\text { concentrations of particulate matter, black carbon, } \\
\text { and ultrafine particles were performed in the same } \\
\text { mine zones where DD was sampled. }\end{array}$ & Passive stubs & NM & $1 \mathrm{~h}$ & NM \\
\hline
\end{tabular}


Table A3. Prevalence and main findings per study.

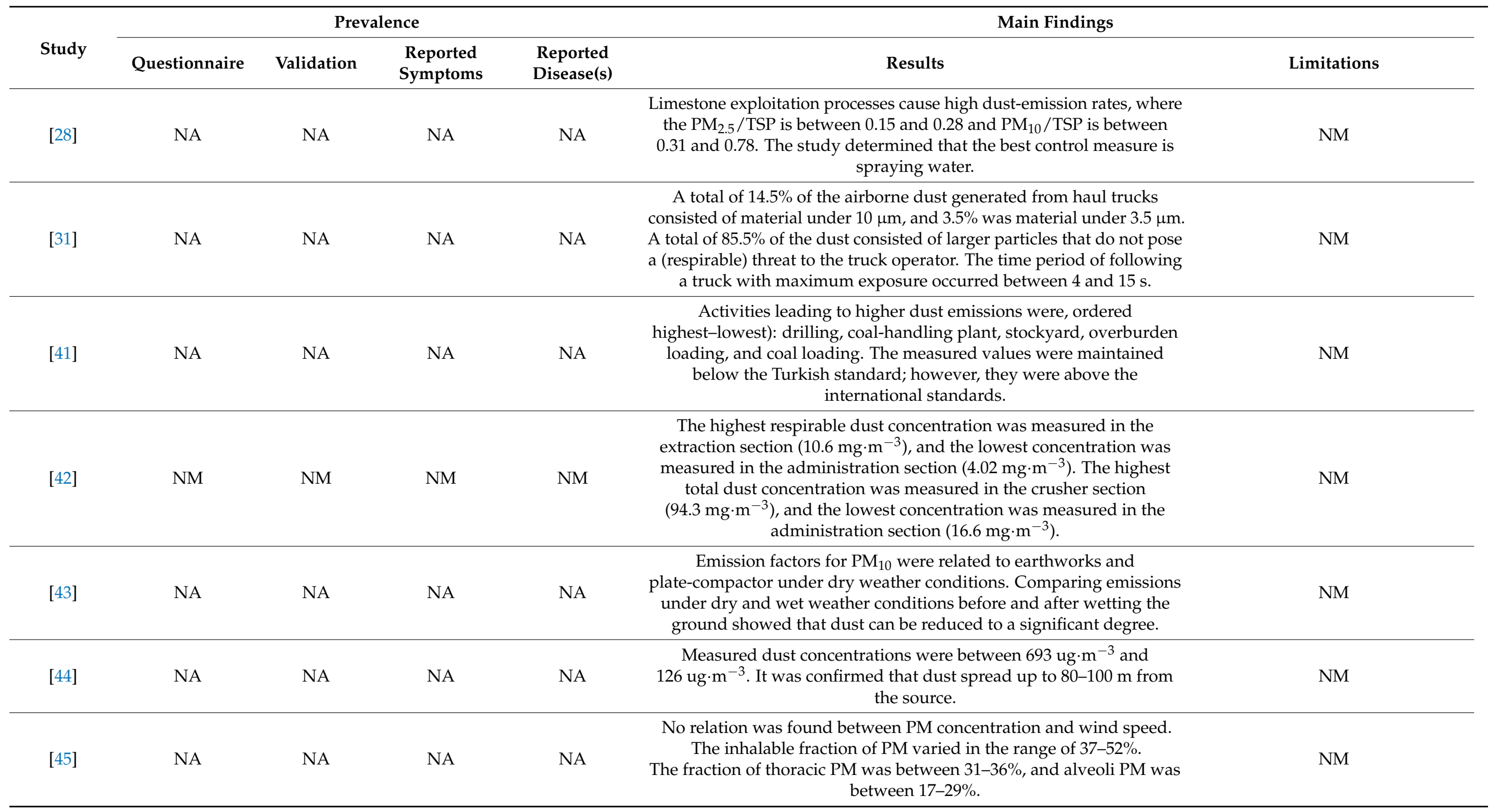


Table A3. Cont.

\begin{tabular}{|c|c|c|c|c|c|c|}
\hline \multirow[b]{2}{*}{ Study } & \multicolumn{4}{|c|}{ Prevalence } & \multicolumn{2}{|l|}{ Main Findings } \\
\hline & Questionnaire & Validation & $\begin{array}{l}\text { Reported } \\
\text { Symptoms }\end{array}$ & $\begin{array}{l}\text { Reported } \\
\text { Disease(s) }\end{array}$ & Results & Limitations \\
\hline [46] & NA & NA & NA & NA & $\begin{array}{l}\text { Overall mean worker exposure to respirable dust was } 0.426 \text {, and to } \\
\text { respirable silica was } 0.091 \mathrm{mg} \mathrm{m}^{-3} \text {. }\end{array}$ & NM \\
\hline [47] & $\mathrm{NM}$ & $\mathrm{NM}$ & $\mathrm{NM}$ & NM & $\begin{array}{l}\text { The highest average concentrations of respirable dust were measured } \\
\text { in Mine 1, and the lowest were measured in Mine } 6 \text {. There was little } \\
\text { variability across the results for the six mines. }\end{array}$ & $\begin{array}{l}\text { Not all SEGs were present at the } \\
\text { all mines. Some samples were } \\
\text { excluded: three were overloaded } \\
\text { with particles, and six exhibited } \\
\text { low sampling volume. } \\
\text { Some samples fell outside of the } \\
\text { limit of detection (LOD). }\end{array}$ \\
\hline [30] & NM & NM & $\mathrm{NM}$ & NM & $\begin{array}{l}\text { Workers in open-cast mines are exposed to high levels of respirable } \\
\text { dust. Considering that lower the particles indicate the harmfulness } \\
\text { level, the job categories can be "ordered" (from highest to lowest): } \\
\text { machine operator, drill man (UG), roof bolter (UG), drill operator (OC), } \\
\text { SDL operator (UG), dozer operator (OC), belt operator (UG), shovel } \\
\text { operator (OC), explosive carrier (UG), trammer (U.G.), and cable } \\
\text { man (UG/OC). }\end{array}$ & NM \\
\hline [48] & NA & NA & NA & NA & $\begin{array}{l}\text { All the measured values were under the permissible level, except for } \\
\text { access to the underground mine. }\end{array}$ & NM \\
\hline [49] & NA & NA & NA & NA & $\begin{array}{l}\text { Results are in the form of percentages. Particulate size fractions were } \\
\text { found to vary according to mine activities. }\end{array}$ & $\begin{array}{l}\text { Due to technical limitations, direct } \\
\text { comparison of the optical-derived } \\
\text { source-concentration data is not } \\
\text { meaningful. }\end{array}$ \\
\hline [50] & $\begin{array}{l}\text { Questionnaire } \\
\text { on respiratory } \\
\text { symptoms }\end{array}$ & Yes & $\begin{array}{l}\text { Cough, } \\
\text { phlegm, } \\
\text { breathlessness, } \\
\text { wheezing, } \\
\text { chest tightness }\end{array}$ & NM & $\begin{array}{c}\text { The results show that the overall dust exposure geometric mean was } \\
0.26 \mathrm{mg} \cdot \mathrm{m}^{-3} \text { over a mean sampling period of } 8 \mathrm{~h} \text { (ranging between } \\
7 \text { and } 11 \mathrm{~h} \text { ). The results regarding respiratory symptoms were: phlegm } \\
(49.1 \%) \text {, breathlessness }(42.9 \%) \text {, cough }(37.5 \%) \text {, wheezing }(18.8 \%) \text {, } \\
\text { and chest tightness }(10.7 \%) \text {. }\end{array}$ & NM \\
\hline [25] & NA & NA & NA & NA & $\begin{array}{l}\text { The results showed that the average PM concentrations in mining sites } \\
\text { were } 1.2-2 \text { times the concentrations at residential sites. PM peak } \\
\text { concentrations were observed during peak production time. }\end{array}$ & $\mathrm{NM}$ \\
\hline
\end{tabular}


Table A3. Cont.

\begin{tabular}{|c|c|c|c|c|c|c|}
\hline \multirow[b]{2}{*}{ Study } & \multicolumn{4}{|c|}{ Prevalence } & \multicolumn{2}{|l|}{ Main Findings } \\
\hline & Questionnaire & Validation & $\begin{array}{l}\text { Reported } \\
\text { Symptoms }\end{array}$ & $\begin{array}{l}\text { Reported } \\
\text { Disease(s) }\end{array}$ & Results & Limitations \\
\hline [51] & NA & NA & NA & NA & $\begin{array}{l}\text { Dust concentrations were highest at downwind points, and the lowest } \\
\text { concentrations were measured upwind from the drill. Increasing wind } \\
\text { speed led to decreased dust concentration. Drilling produces the most } \\
\text { coarse dust particles (TSP and } \mathrm{PM}_{10} \text { ). }\end{array}$ & $\begin{array}{l}\text { Nephelometer capacity is not very } \\
\text { high when measuring all sizes of } \\
\text { particles at once. }\end{array}$ \\
\hline [6] & NA & NA & NA & NA & $\begin{array}{l}\text { The results showed higher concentrations of } \mathrm{PM}_{10} \text { and } \mathrm{PM}_{2.5} \text { during } \\
\text { the winter season. Mining operations contributed to larger fractions of } \\
\text { dust particles. }\end{array}$ & $\mathrm{NM}$ \\
\hline [52] & NA & NA & NA & NA & $\begin{array}{c}\text { The results showed that dust concentration around working mining } \\
\text { equipment is very high. }\end{array}$ & NM \\
\hline [9] & NA & NA & NA & NA & $\begin{array}{l}\text { The results of the study were modelling predictions using the baseline } \\
\text { concentrations and models. }\end{array}$ & NM \\
\hline [53] & NA & NA & NA & NA & $\begin{array}{l}\text { Although every measurement was below } 3 \mathrm{mg} \cdot \mathrm{m}^{-3} \text {, concentrations } \\
\text { exceeded } 50 \% \text { and } 75 \% \text { of the total value at some monitoring stations. }\end{array}$ & $\begin{array}{l}\text { The study was limited to } \\
24 \text { dust samples. }\end{array}$ \\
\hline [8] & NA & NA & NA & NA & $\begin{array}{l}\text { Results showed that dust concentration decreased with increasing } \\
\text { distance with all wind directions and all size categories (TSP, } \mathrm{PM}_{10} \\
\left.\mathrm{PM}_{2.5} \text { and } \mathrm{PM}_{1}\right) \text {. The decrease was most pronounced in the } \\
\text { upwind direction. }\end{array}$ & $\begin{array}{l}\text { Nephelometer capacity is not very } \\
\text { high when measuring all sizes of } \\
\text { particles at once. }\end{array}$ \\
\hline [32] & NA & NA & NA & NA & Average dust concentrations ranged from 1.29 to $19.38 \mathrm{mg} \cdot \mathrm{m}^{-3}$ & $\mathrm{NM}$ \\
\hline [54] & Yes & Yes & NM & NM & $\begin{array}{l}\text { Results showed that dust concentrations in Facility B, when compared } \\
\text { to Facility A, were higher. The highest levels of respirable dust for both } \\
\text { facilities were found at the feeder stations. }\end{array}$ & NM \\
\hline [55] & NA & NA & NA & NA & $\begin{array}{l}\text { The results showed that hauling mined material and crushing activities } \\
\text { are associated with the greatest dust generation of } \mathrm{PM}_{2.5} \text {. }\end{array}$ & NM \\
\hline [56] & NA & NA & NA & NA & $\begin{array}{l}\text { Results show that there are considerable differences in particle size and } \\
\text { composition between locations. In the working fronts, there are } \\
\text { chemical elements, such as } \mathrm{Nb}, \mathrm{Th}, \mathrm{Cr}, \mathrm{Sr}, \mathrm{Li}, \mathrm{As}, \mathrm{Pb}, \mathrm{Cu}, \mathrm{Zr} \text { and } \mathrm{Ni} \text {, } \\
\text { mostly attributed to mining machinery, tyre and brake-wear emissions, } \\
\text { and deposition of dust emitted from gangue working zones. }\end{array}$ & NM \\
\hline
\end{tabular}




\section{References}

1. Gautam, S.; Patra, A.K.; Sahu, S.P.; Hitch, M. Particulate matter pollution in opencast coal mining areas: A threat to human health and environment. Int. J. Min. Reclam. Environ. 2016, 32, 75-92. [CrossRef]

2. Karanasiou, A.; Moreno, N.; Moreno, T.; Viana, M.; de Leeuw, F.; Querol, X. Health effects from Sahara dust episodes in Europe: Literature review and research gaps. Environ. Int. 2012, 47, 107-114. [CrossRef] [PubMed]

3. Prakash, B.B.; Kecojevic, V.; Lashgari, A. Analysis of dust emission at coal train loading facility. Int. J. Min. Reclam. Environ. 2018, 32, 56-74. [CrossRef]

4. Sairanen, M.; Rinne, M.; Selonen, O. A review of dust emission dispersions in rock aggregate and natural stone quarries. Int. J. Min. Reclam. Environ. 2018, 32, 196-220. [CrossRef]

5. Katra, I. Comparison of diverse dust control products in wind-induced dust emission from unpaved roads. Appl. Sci. 2019, 9, 5204. [CrossRef]

6. Tripathy, D.P.; Dash, T.R. Assessment of particulate and trace element pollution in airborne dust around a highly mechanized opencast coal mine in talcher, odisha. J. Min. Sci. 2018, 54, 697-708. [CrossRef]

7. $\quad$ Poinen-Rughooputh, S.; Rughooputh, M.S.; Guo, Y.; Rong, Y.; Chen, W. Occupational exposure to silica dust and risk of lung cancer: An updated meta-analysis of epidemiological studies. BMC Public Health 2016, 16, 1137. [CrossRef] [PubMed]

8. Sairanen, M.; Rinne, M. Dust emission from crushing of hard rock aggregates. Atmos. Pollut. Res. 2019, 10, 656-664. [CrossRef]

9. Chaulya, S.K.; Trivedi, R.; Kumar, A.; Tiwary, R.K.; Singh, R.S.; Pandey, P.K.; Kumar, R. Air quality modelling for prediction of dust concentrations in iron ore mines of Saranda region, Jharkhand, India. Atmos. Pollut. Res. 2019, 10, 675-688. [CrossRef]

10. Abdollahisharif, J.; Bakhtavar, E.; Nourizadeh, H. Monitoring and assessment of pollutants resulting from bench-blasting operations. J. Min. Environ. 2016, 7, 109-118. [CrossRef]

11. Arrandale, V.H.; Kalenge, S.; Demers, P.A. Silica exposure in a mining exploration operation. Arch. Environ. Occup. Health 2018, 73, 351-354. [CrossRef] [PubMed]

12. Bang, K.M.; Mazurek, J.M.; Wood, J.M.; White, G.E.; Hendricks, S.A.; Weston, A. Silicosis Mortality Trends and New Exposures to Respirable Crystalline Silica-United States, 2001-2010. MWR. Morb. Mortal. Wkly. Rep. 2015, 64, 117-120.

13. Andraos, C.; Utembe, W.; Gulumian, M. Exceedance of environmental exposure limits to crystalline silica in communities surrounding gold mine tailings storage facilities in South Africa. Sci. Total Environ. 2018, 619-620, 504-516. [CrossRef] [PubMed]

14. Gonzalez-Garcia, M.; Caballero, A.; Jaramillo, C.; Torres-Duque, C.A. Chronic bronchitis: High prevalence in never smokers and underdiagnosis-A population-based study in Colombia. Chron. Respir. Dis. 2018, 16, 1479972318769771. [CrossRef] [PubMed]

15. Markovič Baluchová, B.; Bačík, P.; Mamová, A. The health impact of mineral dust air pollution on the global and local scale (on the example from Slovakia). Neuroendocrinol. Lett. 2019, 40, 24-28.

16. Bluvshtein, N.; Mahrer, Y.; Sandler, A.; Rytwo, G. Evaluating the impact of a limestone quarry on suspended and accumulated dust. Atmos. Environ. 2011, 45, 1732-1739. [CrossRef]

17. Utembe, W.; Faustman, E.M.; Matatiele, P.; Gulumian, M. Hazards identified and the need for health risk assessment in the South African mining industry. Hum. Exp. Toxicol. 2015, 34, 1212-1221. [CrossRef]

18. Yorio, P.L.; Laney, A.S.; Halldin, C.N.; Blackley, D.J.; Moore, S.M.; Wizner, K.; Radonovich, L.J.; Greenawald, L.A. Interstitial lung diseases in the U.S. mining industry: Using MSHA data to examine trends and the prevention effects of compliance with health regulations, 1996-2015. Risk Anal. 2018, 38, 1962-1971. [CrossRef]

19. Khaniabadi, Y.O.; Polosa, R.; Chuturkova, R.Z.; Daryanoosh, M.; Goudarzi, G.; Borgini, A.; Tittarelli, A.; Basiri, H.; Armin, H.; Nourmoradi, H.; et al. Human health risk assessment due to ambient PM10 and SO2 by an air quality modeling technique. Process Saf. Environ. Prot. 2017, 111, 346-354. [CrossRef]

20. Kang, M.-Y.; Jung, J.; Koo, J.-W.; Kim, I.; Kim, H.-R.; Myong, J.-P. Increased risk of gastric cancer in workers with occupational dust exposure. Korean J. Intern. Med. 2021, 36, S18-S26. [CrossRef]

21. Kim, K.-H.; Kabir, E.; Kabir, S. A review on the human health impact of airborne particulate matter. Sci. Direct 2015, 74, 136-143. [CrossRef] [PubMed]

22. Li, L.; Jiang, M.; Li, X.; Zhou, B. Association between coalmine dust and mortality risk of lung cancer: A meta-analysis. BioMed Res. Int. 2021, 2021, 6624799. [CrossRef] [PubMed]

23. Kahraman, M.M.; Erkayaoglu, M. A data-driven approach to control fugitive dust in mine operations. Min. Metall. Explor. 2021, 38, 549-558. [CrossRef]

24. Wippich, C.; Rissler, J.; Koppisch, D.; Breuer, D. Estimating respirable dust exposure from inhalable dust exposure. Ann. Work Expo. Health 2020, 64, 430-444. [CrossRef] [PubMed]

25. Sahu, S.P.; Yadav, M.; Rani, N.; Das, A.J. Assessment of occupational health exposure to particulate matter around opencast coal mines, India: A case study. Arab. J. Geosci. 2018, 11, 1-11. [CrossRef]

26. Huang, Y.; Bao, M.; Xiao, J.; Qiu, Z.; Wu, K. Effects of PM2.5 on cardio-pulmonary function injury in open manganese mine workers. Int. J. Environ. Res. Public Health 2019, 16, 2017. [CrossRef]

27. Guo, Q.; Ren, W.; Shi, J. Foam for coal dust suppression during underground coal mine tunneling. Tunn. Undergr. Space Technol. 2019, 89, 170-178. [CrossRef]

28. Chang, C.T. Assessment of Influential Range and Characteristics of Fugitive Dust in Limestone Extraction Processes. J. Air Waste Manag. Assoc. 2004, 54, 141-148. [CrossRef] 
29. Bao, J.; Johansson, J.; Zhang, J. An occupational disease assessment of the mining industry's occupational health and safety management system based on FMEA and an Improved AHP Model. Sustainability 2017, 9, 94. [CrossRef]

30. Pandey, J.K.; Agarwal, D.; Gorain, S.; Dubey, R.K.; Vishwakarma, M.K.; Mishra, K.K.; Pal, A.K. Characterisation of respirable dust exposure of different category of workers in Jharia Coalfields. Arab. J. Geosci. 2017, 10, 183. [CrossRef]

31. Reed, W.R.; Organiscak, J.A. The evaluation of dust exposure to truck drivers following the lead Haul truck. In Proceedings of the 2005 SME Annual Meeting, Salt Lake City, UT, USA, 28 February-2 March 2005; pp. 71-79.

32. Tong, R.; Cheng, M.; Yang, X.; Yang, Y.; Shi, M. Exposure levels and health damage assessment of dust in a coal mine of Shanxi Province, China. Process Saf. Environ. Prot. 2019, 128, 184-192. [CrossRef]

33. Duarte, J.; Vaz, M.; Costa, J.T.; Baptista, J.S. Occupational exposure to dust in road construction, earthworks and open-pit mining-A scoping review protocol. Int. J. Occup. Environ. Saf. 2019, 3, 14-19. [CrossRef]

34. Shamseer, L.; Moher, D.; Clarke, M.; Ghersi, D.; Liberati, A.; Petticrew, M.; Shekelle, P.; Stewart, L.A.; Altman, D.G.; Booth, A.; et al Preferred reporting items for systematic review and meta-analysis protocols (prisma-p) 2015: Elaboration and explanation. BMJ 2015, 349, 1-25. [CrossRef] [PubMed]

35. Tricco, A.C.; Lillie, E.; Zarin, W.; O’Brien, K.K.; Colquhoun, H.; Levac, D.; Moher, D.; Peters, M.D.J.; Horsley, T.; Weeks, L.; et al. PRISMA extension for scoping reviews (PRISMA-ScR): Checklist and explanation. Ann. Intern. Med. 2018, 169, 467-473. [CrossRef] [PubMed]

36. Li, D.; Li, Z.; Zhang, Z. The study on the earthworks of green construction based on value engineering. IOP Conf. Ser. Earth Environ. Sci. 2019, 218, 012024. [CrossRef]

37. Wohlin, C. Claes Guidelines for snowballing in systematic literature studies and a replication in software engineering. In Proceedings of the 18th International Conference on Evaluation and Assessment in Software Engineering-EASE'14, London, UK, 13-14 May 2014; ACM Press: New York, NY, USA, 2014; pp. 1-10.

38. Higgins, J.; Altman, D.; Gøtzsche, P.; Jüni, P.; Moher, D.; Oxman, A.; Savović, J.; Schulz, K.; Weeks, L.; Sterne, J.A.C.C. The cochrane collaboration's tool for assessing risk of bias in randomised trials. BMJ 2011, 343, d5928. [CrossRef] [PubMed]

39. Moher, D.; Liberati, A.; Tetzlaff, J.; Altman, D.; Altman, D.; Antes, G.; Atkins, D.; Barbour, V.; Barrowman, N.; Berlin, J.; et al. Preferred reporting items for systematic reviews and meta-analyses: The PRISMA statement. PLoS Med. 2009, 6, e1000097. [CrossRef]

40. Van Eck, N.J.; Waltman, L. Software survey: VOSviewer, a computer program for bibliometric mapping. Scientometrics 2010, 84, 523-538. [CrossRef]

41. Onder, M.; Yigit, E. Assessment of respirable dust exposures in an opencast coal mine. Environ. Monit. Assess. 2009, $152,393-401$. [CrossRef]

42. Gholami, A.; Fani, M.J.; Sadeghi, N. Occupational exposure determination to silica dust in an iron-stone ore and comparison with standard. Int. J. Collab. Res. Intern. Med. Public Health 2012, 4, 1141-1149.

43. Faber, P.; Drewnick, F.; Borrmann, S. Aerosol particle and trace gas emissions from earthworks, road construction, and asphalt paving in Germany: Emission factors and influence on local air quality. Atmos. Environ. 2015, 122, 662-671. [CrossRef]

44. Sastry, V.R.R.; Chandar, K.R.; Nagesha, K.V.V.; Muralidhar, E.; Mohiuddin, M.S. Prediction and analysis of dust dispersion from drilling operation in opencast coal mines. Procedia Earth Planet. Sci. 2015, 11, 303-311. [CrossRef]

45. Gautam, S.; Kumar, P.; Patra, A.K. Occupational exposure to particulate matter in three Indian opencast mines. Air Qual. Atmos. Health 2016, 9, 143-158. [CrossRef]

46. Amran, S.; Latif, M.T.; Khan, M.F.; Goh, E.; Leman, A.M.; Jaafar, S.A. Underestimation of respirable crystalline silica (RCS) compliance status among the granite crusher operators in Malaysian quarries. Air Qual. Atmos. Health 2017, 10, 371-379. [CrossRef]

47. Hwang, J.; Ramachandran, G.; Raynor, P.C.; Alexander, B.H.; Mandel, J.H. A comprehensive assessment of exposures to respirable dust and silica in the taconite mining industry. J. Occup. Environ. Hyg. 2017, 14, 377-388. [CrossRef]

48. Rabeiy, R.E.S.; ElTahlawi, M.R.; Boghdady, G.Y. Occupational health hazards in the Sukari Gold Mine, Egypt. J. Afr. Earth Sci. 2018, 146, 209-216. [CrossRef]

49. Richardson, C.; Rutherford, S.; Agranovski, I. Characterization of particulate emissions from Australian open-cut coal mines: Toward improved emission estimates. J. Air Waste Manag. Assoc. 2018, 68, 598-607. [CrossRef]

50. Rusibamayila, M.; Meshi, E.; Mamuya, S. Respiratory impairment and personal respirable dust exposure among the underground and open cast gold miners in Tanzania. Ann. Glob. Health 2018, 84, 419-428. [CrossRef]

51. Sairanen, M.; Selonen, O. Dust formed during drilling in natural stone quarries. Bull. Eng. Geol. Environ. 2018, 77, 1249-1262. [CrossRef]

52. Wanjun, T.; Qingxiang, C. Dust distribution in open-pit mines based on monitoring data and fluent simulation. Environ. Monit. Assess. 2018, 190, 632. [CrossRef]

53. Mankar, P.; Mandal, B.B.; Chatterjee, D. Monitoring and assessment of airborne respirable limestone dust and free silica content in an Indian mine. J. Health Pollut. 2019, 9, 190904. [CrossRef] [PubMed]

54. Sepadi, M.M.; Chadyiwa, M.; Nkosi, V. Platinum mine workers exposure to dust particles emitted at mine waste rock crusher plants in limpopo, South Africa. Int. J. Environ. Res. Public Health 2020, 17, 655. [CrossRef] [PubMed]

55. Ambastha, S.K.; Haritash, A.K. Emission of respirable dust from stone quarrying, potential health effects, and its management. Environ. Sci. Pollut. Res. 2021, 29, 6670-6677. [CrossRef] [PubMed] 
56. Trechera, P.; Moreno, T.; Córdoba, P.; Moreno, N.; Zhuang, X.; Li, B.; Li, J.; Shangguan, Y.; Dominguez, A.O.; Kelly, F.; et al. Comprehensive evaluation of potential coal mine dust emissions in an open-pit coal mine in Northwest China. Int. J. Coal Geol. 2021, 235, 103677. [CrossRef]

57. Zilaout, H.; Vlaanderen, J.; Houba, R.; Kromhout, H. 15 years of monitoring occupational exposure to respirable dust and quartz within the European industrial minerals sector. Int. J. Hyg. Environ. Health 2017, 220, 810-819. [CrossRef] [PubMed]

58. Dahmann, D.; Taeger, D.; Kappler, M.; Büchte, S.; Morfeld, P.; Brüning, T.; Pesch, B. Assessment of exposure in epidemiological studies: The example of silica dust. J. Expo. Sci. Environ. Epidemiol. 2008, 18, 452-461. [CrossRef]

59. Zilaout, H.; Houba, R.; Kromhout, H. Temporal trends in respirable dust and respirable quartz concentrations within the European industrial minerals sector over a 15-year period (2002-2016). Occup. Environ. Med. 2020, 77, 268-275. [CrossRef]

60. Bell, J.L.; Mazurek, J.M. Trends in pneumoconiosis deaths-United States, 1999-2018. MMWR. Morb. Mortal. Wkly. Rep. 2020, 69, 693-698. [CrossRef] 